\title{
MOLECULAR APPLICATIONS OF CANDIDATE GENES IN GENETIC IMPROVEMENT PROGRAMS IN LIVESTOCK
}

\author{
M.H. Khalil \\ Department of Animal Production, Faculty of Agriculture at Moshtohor, Benha University, Egypt \\ Corresponding author email: maher.khalil@fagr.bu.edu.eg
}

Received: 1/9/2019 Accepted: 26/10/2019

\section{SUMMARY}

In livestock, selection programs utilizing quantitative genetics are time consuming due to long generation interval and sometimes of lowly heritable traits. Several genes to be used in selection based on their biological actions or those located in genome regions of identified Quantitative Trait Loci (QTLs) have been regarded as candidate genes affecting economic traits in livestock. Such candidate genes have successful application in identifying several DNA markers associated with production traits. Utilization of candidate genes is one of the primary methods to determine the specific genes related to the economic traits in farm animals. Using molecular techniques is a good way to achieve fast genetic improvement through identifying the genes or QTLs that affect the trait of economic importance in farm animals. This approach has enabled opportunities to enhance genetic improvement programs by direct selection on genes or genomic regions through markerassisted selection (MAS) and gene introgression. Mapping of QTLs was ta crucial approach to identify genes related to complex traits at the genome-wide level. Recently, a genome wide association study (GWAS) succeeded in identifying the casual genes, using the sequence variations by single nucleotide polymorphism $(S N P)$. GWAS is an ideal technique to discover the major genes for complex traits and is a novel way to study the genetic mechanism of such traits. Many genes affecting milk traits such as GHR and PRLR genes were identified in cattle using $\boldsymbol{G W A S}$ method. The objectives of the present reviewed article are: 1) Applying a fine chromosomal mapping for localizing the QTL affecting some economic traits using specific microsatellite markers or SNP's in Egyptian farm animals, 2) Selecting the molecular markers to be considered in genetic variability and genotyping, 3) Identifying the candidate genes and causative mutations associated with economic traits in these animals (e.g. cattle, buffalo, sheep, goats and rabbits), 4) Determining the genetically significant SNP markers associated with the economic traits, 5) To perform GWAS using SNP to detect potential causative mutations and genomic regions affecting some productive and reproductive traits in the Egyptian farm animals. A list of the necessary procedures and executable approach are suggested for a genetic improvement program of Egyptian farm animals using the molecular approaches, that may be outlined as: 1) Determining the main objectives, 2) Collecting and recording the phenotypic data, 3) Evaluating the animals genetically, 4) Determine the list of main equipments and chemicals required, 5) Collecting the blood samples and DNA extraction, 6) Genotyping the animals using SNPs markers, 7) Applying the bioinformatics analyses for candidate genes and detecting QTLs, 8) Preparing and editing the genotyping files, 9) Estimating the average yield deviation for each trait, 10) Applying the Genome-Wide Association Study (GWAS), 11) Applying SNP association test, 12) Applying genome-wide complex trait analysis (GCTA), 13) Estimating the genomic breeding values $(G B V)$ to be applied in genomic selection, 14) Evaluating the prediction accuracy (EBV vs $G E B V)$, 15) Estimating the Genomic Best Linear Unbiased Predictions (GBLUP) and SNP-GBLUP, 16) Estimating the genomic breeding values $(G B V)$ to be applied in genomic selection $(G S)$.

Keywords: Livestock, Molecular applications, Candidate genes, Genetic improvement programs, GWAS, Genomic Breeding Values (GBV)

\section{BACKGROUND}

Molecular genetics can be used to identify the genes or chromosomal regions (Quantitative Trait Loci) that affect the trait of importance in livestock production (Andersson, 2001). Mapping of quantitative trait loci (QTL) was suggested as the perfect approach to identify genes related to complex traits at genome-wide study using microsatellite markers. To date in the whole genome, genome wide association study (GWAS) was used in applying the technique of single nucleotide polymorphism (SNP).
GWAS has become feasible in domestic animals as a result of the development of large collections of SNPs (such as Illumine Bovine SNP50 Bead Chip that contain 50,000 SNPs) and the development of cost-effective methods for large-scale SNP analysis. Compared with traditional QTL mapping strategies, GWAS has major advantages both in the power to detect causal variants with modest effects, and in defining narrower genomic regions that harbor causal variants. Many genes for milk traits were identified in cattle using GWAS method such as ABCGDGAT1, SCD1, STATA5, ACSS2, AGPAT6,

Issued by The Egyptian Society of Animal Production 
PPARGC1A, GHR and PRLR (Zhang et al. 2012, Sharma et al. 2015).

The main challenge in any genetic improvement program is the availability of data and information about relationship between relatives. Since the markers effect can be calculated where the phenotype is available and consequently the genomic breeding value (GEBV) for a given trait can be estimated for animals which do not have a phenotype based on the markers effect that has been previously calculated in the reference population (Meuwissen et al. 2001). This approach can reduce the cost of breeding schemes by about $92 \%$ (Schaeffer 2006) and double the rate of genetic gain (De Roos et al. 2011). Genomic selection (GS) is a variant of markerassisted selection that uses genome-wide single nucleotide polymorphisms (SNP) to predict individual breeding values for selection (Herraez et al., 2005). Numerous studies have shown encouraging results of applying GS in selection of purebreds (Hayes et al., 2009). However, except in dairy cattle, most livestocks are crossbreds with advantages of heterosis and breed complementarity. Recent studies have shown that GS is also an appealing method to select purebreds and crossbreds performance (Dekkers, 2007). As compared to alternative methods, genomic selection can give substantially greater response to selection (Piyasatian et al., 2007), lower the rate of inbreeding (Dekkers, 2007), and it does not require a systematic collection of pedigree that connects crossbreds to purebreds. Moreover, it is not necessary to measure the crossbred phenotypes every generation of GS, because, in theory, the estimates of SNP effects can be applied through a few generations with only a negligible loss in prediction accuracy.

Numerous strategies and statistical approaches have been developed to meet the conceptual and technical challenges and to take full advantage of the wide opportunities provided by GWAS. However, several pathway-based GWAS algorithms have been developed and implemented in different software packages (Fan et al. 2015). SNP2GO is one of the software used to perform pathway analysis to identify the genes and mechanisms that are involved in the expression of the trait under study (Szkiba et al. 2014). Finally, SNPCHiMP is a web database that can be used for genomic annotation; determine the physical position of SNPs and to determine if the SNPS are involved in intronic or intergenic region of genes (Nicolazzi et al. 2014).

\section{Mapping of quantitative trait loci (QTL):}

The identification and utilization of QTL provide potential for more rapid genetic improvement in selection programs, especially for traits that are difficult to improve with traditional selection (Ikeobi et al., 2002).

In the last 15 years, several experimental livestock populations (F0, F1, F2 and F3) have been constructed from different breeds for use in gene and
QTL mapping studies (Bulut et al., 2013). Furthermore, the chromosomal scanning studies have been conducted to exemplify the chromosomal regions affecting phenotypic all traits, including economic traits in different livestock breeds. These studies are ongoing for identification of quantitative trait genes (QTGs) and quantitative trait nucleotide (QTNs) controlling these traits. Molecular data will be analyzed using the following mixed model including the fixed effects along with the additive and dominance effects of QTL as random effects (Haley et al., 1994; Manly et al., 2001):

$\mathrm{yij}=\mathrm{Xijb}+\mathrm{Zaa}+\mathrm{Zdd}+\mathrm{ei}$

Where: yij is the phenotype of animals, $\mathrm{Xij}$ is the designed matrix, and $b$ is the vector of coefficients for fixed effects, $a$ is the vector of additive effect of the QTL, $d$ is the vector of dominance effect of the QTL, Za the probability of one homozygous type at the putative QTL locus given the marker information minus the probability of the other homozygous type at the locus given the marker information for the animal $\mathrm{i}, \mathrm{Zd}$ is the probability of being heterozygous at the putative QTL locus given marker genotypes for the animal $\mathrm{i}$, and ei is the random error, typically assumed to be normally distributed as $\mathrm{N}(0, \sigma 2)$ (Haley and Knott, 1992).

\section{Molecular markers to be used:}

The genetic markers can be used to enhance the genetic improvement of breeding stock through marker-assisted selection (MAS). Marker-Assisted Selection is the most widely used application of marker systems in animal breeding. Using microsatellites as direct marker that increase the accuracy of selection from 0.63 to 0.83 (Solberg et al., 2008).

Molecular markers can be used to detect the genetic variability, either within or among individuals, families, and populations. As stated byErhardt and Weimann (2007), the majority of molecular markers currently used are microsatellite markers, STRs (short tandem repeats) and SNPs (single nucleated polymorphism). Among all types of the molecular markers, the microsatellites are used as the most widely used markers for the analysis of genetic diversity and population structure in poultry(Maudet et al., 2002). Nowadays, DNA molecular marker techniques are widely applied in the fields of germplasm identification, phylogenetic, and genetic structural analysis(Yang et al., 2013). Accordingly, the microsatellite has been used to develop the markers from genes and they have been referred to as genic molecular markers (GMMs) or functional markers (FMs).

Definite number of microsatellite markers covering autosomal linkage groups and the sex $\mathrm{Z}$ chromosome to be considered in genotyping F0 grandparents, F1 and F2 offspring. These markers to be selected based on the degree of polymorphism and the genome coverage recommended in the molecular genetic characterization of animal genetic resources 
(FAO, 2011). Detailed information about selected microsatellites are available at the FAO website (www.dad.fao.org/en/

refer/library/guideline/marker.pdf). The assessment of markers was based on their positions on the consensus map. A target for marker spacing of 10 $\mathrm{CM}$ was used to test markers across the genome (http://www.ncbi.nlm.nih.gov/mapview and http://www.thearkdb.org).

Genetic markers are used to provide information as bioinformatics indicators about polymorphism in allelic genotype at a given locus. The availability of molecular markers in farm animals allows the detailed analyses and evaluation of genetic diversity and furthermore the detection of genes influencing economically important traits. Molecular markers should not be considered as normal genes as they usually do not have any biological effect.

As stated by Seidel (2009), the genomic selection using the SNP markers is a powerful new tool because: 1) SNP can be detected by a number of methods such as PCR-RFLP, 2) SNP is relatively new technology using DNA chips that can be used for large scale screening of numerous samples in a minimal amount of time (Fontanesi et al., 2008), 3) SNP is the most recent contribution to study DNA sequence variation, and 4) SNP represents the most innovative molecular marker in genotyping studies. However, recent advances in high-throughput DNA sequencing, computer software and bioinformatics have facilitated the identification of SNP as molecular markers.

The microsatellite has been used to develop the markers from genes and they have been referred as genic molecular markers (GMMs) or functional markers (FMs). They compared the SNP results with the analysis using microsatellites and concluded that: 1) microsatellites provide high clustering success due to high polymorphic nature, 2) SNP provides broader genome coverage and reliable estimates of genetic relatedness in the genome, and 3) SNP considered to be an efficient and cost-effective genetic tool. In comparison with the highly polymorphic microsatellite markers, SNP has the following advantages: (1) It is less informative due to its balletic nature, (2) It has significant advantages over microsatellite markers as a basis for high-resolution whole genome allelotyping because of their abundance, even spacing, and stability across the genome and (3) it is used to identify the paternal and maternal alleles of a given gene based on polymorphisms. As stated by Brown (1999), SNP as a marker has the following advantages over the other types of genetic markers: 1) It has high level of polymorphism, 2) It is distributed throughout the genome, 3) It has the presence within coding regions,
4) It has introns and regions that flank genes, 5) It is simple and unambiguous assay technique, 6) It has stable Mendelian inheritance, and 7) It has low levels of spontaneous mutation, (8) SNPs are less informative due to their biallelic nature, (9) SNP has significant advantages over microsatellite markers as a basis for high-resolution whole genome allelotyping because of their abundance, even spacing, and stability across the genome, and (10) SNP technique is used to identify the paternal and maternal alleles of a given gene based on polymorphisms.(Seidel, 2009)reported that genomic selection using the SNP markers is a powerful new tool for genetic selection and this is because: 1) SNPs can be detected by a number of techniques such as PCR-RFLP, 2) SNP is relatively new technology using DNA chips that can be used for large scale screening of numerous samples in a minimal amount of time(Fontanesi et al., 2008), 3) SNP is the most recent contribution to study DNA sequence variation, and 4) SNP represents the most innovative molecular marker in genotyping studies.

\section{Identification of candidate genes in cattle:}

Research on numerous candidate genes have been conducted and confirmed the fact that there are polymorphic associations between candidate genes and economic traits in cattle (Table 1).

In marker-assisted selection of dairy cattle, some genes are proposed as potential candidates associated with dairy performance traits. Among the various candidates, the prolactin gene seems to be promising, because it plays a crucial role in mammary gland development and in the initiation and maintenance of lactation and expression of milk protein genes. Prolactin (PRL) and Lactoferrin (LF) genes play important regulatory functions in mammary gland development, milk secretion, and expression of milk protein genes (Zhag et al, 2008). Lactoferrin gene is highly polymorphic and it has been shown that some of its variants are related to milk production traits and mastitis resistance in dairy cattle (Kaminski et al., 2006; Wojdak-Maksymiec et al., 2006). As stated by Brym et al. (2005), the prolactin gene is a potential quantitative trait locus and could be used as genetic marker of production traits in dairy cattle. Prolactin is known to have diverse biological functions such as water and electrolyte balance, growth and development, immune and reproductive function (Gregerson, 2006). Bovine prolactin gene is located on chromosome 23, which is composed of five exons and four introns (Dybus et al., 2005). Several polymorphic sites have been detected within PRL and LF genes (Deepika and Salar, 2014). 
Table 1. Candidate genes associated with performance and milk traits in Cattle as cited in literature

\begin{tabular}{lllll}
\hline Chr* & Candidate gene & \multicolumn{2}{l}{ Trait associated withBreed or line } \\
gene
\end{tabular}
(STAT1)

Zinc finger and BTB domainBody measurementChinese cattle breeds Liu et al., 2013 containing 38 (ZBTB38) traits

$2 \quad \operatorname{Myostatin}(M S T N)$

Growth and carcass(Belgian Blue $\times$ British Breed) Casas et al., 2004

Prka genes(prkay3) traits

Glutamicacid decarboxylase 1Growth traits (GAD1) Milk, fat and protein

Holstein, Jersey and CanadienneMacGillivary, 2009

Insulin-like growth factorGrowth, carcass

Qinchuan, Jiaxian Red Li et al., 2010a binding protein-2 (IGFBP-2) and meat quality

Nanyang

Brahman, Hereford, MainePagan, 2002

Anjou, Simmental, Tarentaise,

Salers,Shorthorn and Black

Angus

3 Prka genes(prkaa2)

Milk, fat and protein

Holstein, Jersey and CanadienneMacGillivary, 2009

Heat shock protein family AHeat tolerance

(Hsp70) member 6 (HSPA6)

CYP4A11 CNV gene

Growth traits

Angus

Baena et al., 2018

Jinnan, Qinchuan, Jiaxian Red,Yang et al., 2017

Nanyang and Chinese Red

Steppe

$4 \quad$ Prka genes(prkay2)

Milk, fat and protein

Holstein, Jersey and Canadians MacGillivary, 2009

Leptin gene (LEP)

Milk production

Carcass Traits

Angus, Hereford, SimmentalBuchanan et al., 2005; and Reggiana Fontanesi et al., 2015

Calcium channel, voltage-Mastitis incidence

Sahiwal and Karan Fries

Magotra et al., 2019 dependent, alpha-2/ and milk production delta subunit 1 (CACNA2D1) traits

$5 \quad$ Prka genes(prkayl) Milk, fat and protein

Oxidized low densityMilk production Holstein

lipoprotein (lectin-like) receptor

1 (ORL1)

Apoptosis peptide activatingFertility

FACTOR 1 (APAF1)

6 Casein kappa (CSN3)

Milk production

ATP-binding cassette, sub-Milk production family $\mathrm{G}$ (WHITE), member 2

(ABCG2)

Secreted phosphoprotein 1Milk production (SPP1)

V-kitHardy-Zuckerman4 felineMilk production sarcomaviraloncogenehomolog

(KIT)

Lactoglobulin beta (LGB) Milk production

peroxisome proliferator-Meat quality traits activated receptor gamma coactivator 1 alpha (PPARGC1A)

Holstein, Jersey and CanadienneMacGillivary, 2009

Holstein

Reggiana

Reggiana

Holstein

Reggiana

Italian Holstein

Reggiana

Reggiana
Khatib et al., 2006; Fontanesi et al., 2015

VanRaden et al., 2011

Fontanesi et al., 2015; Medrano and Cordova, 1990

Russo et al., 2007; Fontanesi et al., 2015

Khatib et al., 2007; Fontanesi et al., 2015

Fontanesi et al., 2014; Fontanesi et al., 2015; Fontanesi et al., 2010

Fontanesi et al., 2015; Medrano and Cordova, 1990

Holstein, Charolais, Limousin,Sevane et al., 2013

Simmenthal, Piedmontese,

Asturiana de los Valles,

Pirenaica, Danish Red,

Marchigiana, Asturiana de la

Montaña and Avileña-

NegraIbérica 
Cont. Table 1. Candidate genes associated with performance and milk traits in Cattle as cited in literature

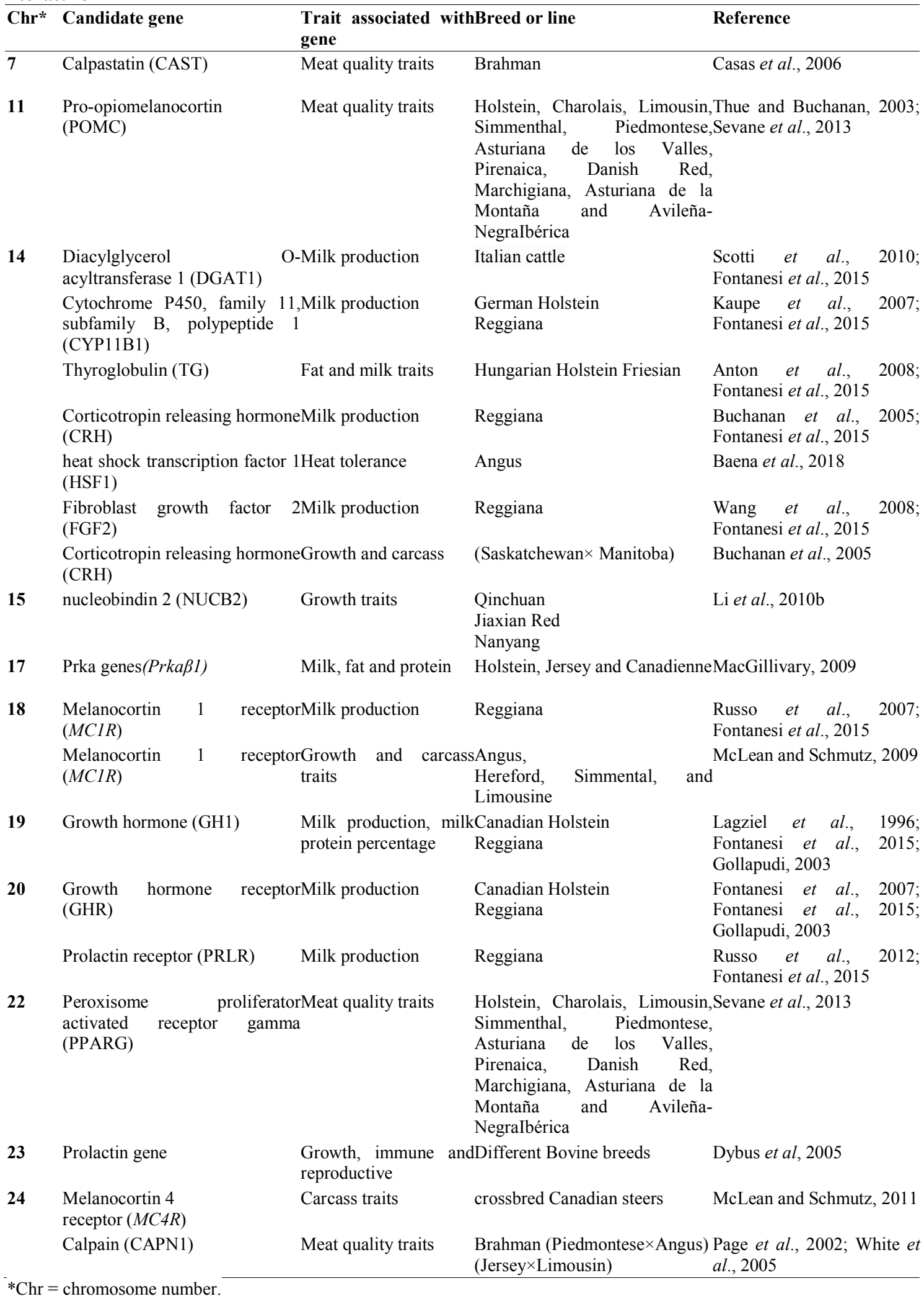

Identification of candidate genes in buffaloes:

Generally, the performance of buffalo cow suffering from many production and reproduction problems such as low milk yield, Short lactation periods, long dry periods, silent estrus, low conception rate, delayed maturity, long calving 
intervals and a large number of days open (Aziz et al. 2001;Biomy 2012). These problems cause low efficiency of productive and reproductive performance. Some of the previous traits especially reproductive traits had low heritability, in addition unavailability of performance records with smallholder causing difficulty to apply traditional selection programs to improve productive and reproductive performance of buffalo cows. Therefore, it is difficult to detect the candidate genes for traits of interest. Recently, genome wide association study (GWAS) could be used to identify casual genes uses sequences variations mainly single nucleotide polymorphism (SNP).

Identification and utilization of candidate genes for economically important traits is one of the most important long-term goals to improve reproduction and productive efficiency in buffalo populations. In order to improve this efficiency, we need to understand what genes and their proteins are involved in regulation of key reproductive events; how genetic variations lead to significant physiological differences in reproductive performance, and how genes and environment interact to achieve optimum productivity. The studies in buffaloes have shown that members of the transforming growth factor beta $(T G F \beta)$ super family, some other genes have identified $B M P 15$, $B M P R 1 B$ and $G D F 9$ as major genes responsible for fertility and/or sterility in different buffalo breeds (Table 2).

Table 2. Candidate genes associated with economic traits in different breeds of buffaloes as cited in literature

\begin{tabular}{|c|c|c|c|c|}
\hline Chr* & Candidate gene & Traits associated with gene & Breed used & $\begin{array}{l}\text { Reference and country } \\
\text { of work }\end{array}$ \\
\hline \multirow[t]{2}{*}{1} & $\begin{array}{l}\text { Melatoninreceptor } \\
\text { (MTRN1A) }\end{array}$ & $\begin{array}{l}\text { AReproduction, milk, fat an } \\
\text { protein production }\end{array}$ & $\begin{array}{l}\text { dSão Paulo State } \\
\text { Bubalusbubalis }\end{array}$ & $\begin{array}{l}\text { Zetouni et al., 2014, } \\
\text { Brazil }\end{array}$ \\
\hline & & & $\begin{array}{l}\text { Terra Firme, } \\
\text { Várzea (VA) }\end{array}$ & $\begin{array}{l}\text { Barbosa et al., 2016, } \\
\text { Brazil }\end{array}$ \\
\hline \multirow[t]{3}{*}{2} & Prolactin-like (PRL) & Milk yield and quality & Nili-Ravi & $\begin{array}{l}\text { Nadeem and Maryam, } \\
\text { 2016, Pakistan }\end{array}$ \\
\hline & & Milk production & Buffalo MediterraneanItaliana & Li et al., 2017, China \\
\hline & \multicolumn{2}{|c|}{$\begin{array}{l}\text { Signaltransducer and activatorCarcass } \\
\text { of transcription1(STAT1) }\end{array}$} & Water buffaloes & $\begin{array}{l}\text { Deng et al., 2015, } \\
\text { China }\end{array}$ \\
\hline 3 & $\begin{array}{l}\text { Adrenoceptor alpha } \\
\text { (ADRAIA) }\end{array}$ & AMilk production & Dairy buffaloes & $\begin{array}{l}\text { Araújo et al., 2015, } \\
\text { Brazil }\end{array}$ \\
\hline \multirow[t]{2}{*}{4} & $\begin{array}{l}\text { Insulin like growth factor } \\
\text { (IGF-I) }\end{array}$ & $\begin{array}{l}\text { 1Milk production } \\
\text { Constituents }\end{array}$ & $\begin{array}{l}\text { Meshing, } \\
\text { Surti, Jaffarabadi, }\end{array}$ & $\begin{array}{l}\text { Fatima et al., 2009, } \\
\text { India }\end{array}$ \\
\hline & Alpha-2-macroglobulin $(A 2 M)$ & \multicolumn{2}{|c|}{$\begin{array}{l}\text { Milk yield and fat, proteinMurrah buffaloes } \\
\text { percentages }\end{array}$} & $\begin{array}{l}\text { Freitas et al., 2016, } \\
\text { Brazil }\end{array}$ \\
\hline 5 & $\begin{array}{l}\text { Insulin-like growth factor } \\
\text { (IGF2) }\end{array}$ & 2Body weight and gains & Egyptian water buffalo & $\begin{array}{l}\text { Abo-Al-Ela et al., } \\
\text { 2014, Egypt }\end{array}$ \\
\hline 6 & Casein alpha s2 (CSNS2) & $\begin{array}{l}\text { Milk yield, fat, protei } \\
\text { casein, solids not fat and tot } \\
\text { Solids }\end{array}$ & $\begin{array}{l}\text {,Bhadawari, Murrah, } \\
\text { IMehsana, Surti }\end{array}$ & $\begin{array}{l}\text { Misra et al., 2008, } \\
\text { India }\end{array}$ \\
\hline \multirow[t]{2}{*}{7} & Kappa-casein (CSN3) & $\begin{array}{l}\text { Fat, protein, lactose, } \\
\text { total solids }\end{array}$ & Lactating buffaloes & $\begin{array}{l}\text { Otaviano et al., 2005, } \\
\text { Brazil }\end{array}$ \\
\hline & $\begin{array}{l}\text { Secreted phosphoprotein } \\
\text { (SPP1) }\end{array}$ & 1Semen production & Water buffaloes & $\begin{array}{l}\text { Rolim Filho et al., } \\
\text { 2013, Brazil }\end{array}$ \\
\hline \multirow[t]{4}{*}{8} & Leptin (LEP) & Economic traits & Murrah buffalo & $\begin{array}{l}\text { Datta et al., 2012, } \\
\text { India }\end{array}$ \\
\hline & & $\begin{array}{l}\text { Milk yield, fat, } \\
\text { protein percentages }\end{array}$ & Sa o Paulo & $\begin{array}{l}\text { Zetouni et al., 2013, } \\
\text { Brazil }\end{array}$ \\
\hline & & Milk and fat production & $\begin{array}{l}\text { Mehsana, Marathwada, } \\
\text { Chilika, Jaffarabadi, } \\
\text { Murrah, Nili-Ravi, } \\
\text { Toda, Pandharpuri, }\end{array}$ & $\begin{array}{l}\text {,Tanpure et al., 2012, } \\
\text { India }\end{array}$ \\
\hline & & Carcass trait & Egyptian buffaloes & $\begin{array}{l}\text { Othman et al., 2011, } \\
\text { Egypt }\end{array}$ \\
\hline
\end{tabular}


Cont. Table 2. Candidate genes associated with economic traits in different breeds of buffaloes as cited in literature

\begin{tabular}{|c|c|c|c|c|}
\hline Chr* & Candidate gene & Traits associated with gene & Breed used & $\begin{array}{ll}\text { Reference } & \text { and } \\
\text { country of work }\end{array}$ \\
\hline \multirow[t]{2}{*}{10} & $\begin{array}{l}\text { Insulin-like growth factor } \\
\text { receptor (IGF2R) }\end{array}$ & 2Body weights and gains & Egyptian buffalo & $\begin{array}{l}\text { El-Magd et al., 2014, } \\
\text { Egypt }\end{array}$ \\
\hline & $\begin{array}{l}\text { Insulin-like growth factor } \\
\text { receptor (IGF1R) }\end{array}$ & 1Growth traits & Egyptian buffalo & $\begin{array}{l}\text { El-Magd et al., 2013, } \\
\text { Egypt }\end{array}$ \\
\hline 12 & $\begin{array}{l}\text { Insulin-like growth factor } \\
\text { (IGF2) genes }\end{array}$ & 2Body weight and daily gains & Egyptian buffalo & $\begin{array}{l}\text { El-Magd et al., 2014, } \\
\text { Egypt }\end{array}$ \\
\hline \multirow[t]{2}{*}{14} & Oxytocin/neurophysin I (OXT) & Milk production traits & Dairy buffaloes & $\begin{array}{l}\text { Araújo et al., 2015, } \\
\text { Brazil }\end{array}$ \\
\hline & Oxytocin/neurophysin I(OXT) & Milk yield & Buffalo MediterraneanItaliana & $\begin{array}{l}\text { Pauciullo et al., 2012a, } \\
\text { Italy }\end{array}$ \\
\hline 15 & $\begin{array}{l}\text { Diacylglycerol } \\
\text { acyltransferase } 1 \text { (DGAT1) }\end{array}$ & -Milk production, Quality trait & sThe Murrah buffaloes & $\begin{array}{l}\text { de Freitas et al., 2016, } \\
\text { Brazil }\end{array}$ \\
\hline 17 & Calpain 1 (CAPN1) & Carcass trait & Egyptian buffaloes & $\begin{array}{l}\text { Othman et al., 2011, } \\
\text { Egypt }\end{array}$ \\
\hline 19 & Casein alpha s1 (CSNS1) & $\begin{array}{l}\text { Milk yield, fat, protein } \\
\text { casein, solids not fat and tota } \\
\text { Solids }\end{array}$ & $\begin{array}{l}\text {,viz. Bhadawari , Murrah, } \\
\text { lMehsana, } \\
\text { Surti }\end{array}$ & $\begin{array}{l}\text { Misra et al., 2008, } \\
\text { India }\end{array}$ \\
\hline 21 & Oxytocin receptor (OXTR) & Milk and fatty acids & $\begin{array}{l}\text { Italian Mediterranean river } \\
\text { buffalo }\end{array}$ & $\begin{array}{l}\text { Cosenza et al., 2017, } \\
\text { Italy }\end{array}$ \\
\hline 22 & Melanocortin 4receptor $(M C 4 R)$ & Milk production & Water buffaloes & $\begin{array}{l}\text { Deng et al., 2016, } \\
\text { China }\end{array}$ \\
\hline 23 & Stearoyl-CoA desaturase(SCD) & Milk yield & Located buffaloes & $\begin{array}{l}\text { Pauciullo et al., 2012b, } \\
\text { Italy }\end{array}$ \\
\hline
\end{tabular}

Identification of candidate genes in sheep and between candidate genes and economic traits in sheep goats: and goats.

Numerous associations' studies cited in Table $3 \& 4$ have been investigated to clarify the relationship

Table 3. Candidate genes associated with economic traits in sheep as cited in literature

\begin{tabular}{|c|c|c|c|c|}
\hline Chr* & Candidate gene & $\begin{array}{l}\text { Traits associated } \\
\text { gene }\end{array}$ & withBreed used & $\begin{array}{l}\text { Reference and country of } \\
\text { work }\end{array}$ \\
\hline 1 & $\begin{array}{l}\text { POU class } 1 \text { homeobox } 1 \text { gen } \\
\text { (PIT1) }\end{array}$ & eWool weights & Makooei & Negahdary et al., 2014 \\
\hline 2 & Myostatin gene (MSTN) & $\begin{array}{l}\text { Muscling, } \\
\text { body weight, } \\
\text { meat production }\end{array}$ & $\begin{array}{l}\text { Norwegian White, Baluchi } \\
\text { Karnobat Merino }\end{array}$ & $\begin{array}{l}\text { Tellam et al., 2012; } \\
\text { Dimitrova } \text { et al., } 2017\end{array}$ \\
\hline \multirow[t]{5}{*}{3} & Beta-lactoglobulin gene ( $\beta$-LG) & $\begin{array}{l}\text { Milk production } \\
\text { composition }\end{array}$ & andAwassi & Jawasreh et al., 2019 \\
\hline & $\begin{array}{l}\text { Insulin like growth factor I gen } \\
\text { (IGF-I) }\end{array}$ & eWool weights & Makooei & Negahdary et al., 2014 \\
\hline & $\begin{array}{l}\text { Thyrotropin releasing hormon } \\
\text { degrading enzyme gene TRHDE }\end{array}$ & eGrowth traits & New Ujumqin & Zhang et al., 2016 \\
\hline & Keratin gene KRT81, 85 & Wool traits & $\begin{array}{l}\text { Chinese Merino (Xinjiang } \\
\text { Type) }\end{array}$ & gSulayman et al., 2018 \\
\hline & $\begin{array}{l}\text { alpha-lactalbumin gene (-LA } \\
\text { LALBA) }\end{array}$ & :Milk traits & East Friesian Dairy Lacaune & Giambra et al., 2014 \\
\hline 4 & Leptin gene (LEP) & Wool weights & Makooei & Negahdary et al., 2014 \\
\hline \multirow[t]{2}{*}{5} & Calpastatin gene & \multicolumn{2}{|c|}{$\begin{array}{l}\text { Body weights and gains,Sufflock, Traghee } \\
\text { meat production } \quad \text { Karnobat Merino }\end{array}$} & $\begin{array}{l}\text { Chung and Davis, } \\
\text { 2012;Dimitrova et al., } 2017\end{array}$ \\
\hline & $\begin{array}{l}\text { Myocyte enhancer factor } 2 \mathrm{~B} \\
\text { gene MEF2B }\end{array}$ & BGrowth traits & New Ujumqin & Zhang et al., 2016 \\
\hline
\end{tabular}


Cont. Table 3. Candidate genes associated with economic traits in sheep as cited in literature

\begin{tabular}{|c|c|c|c|c|}
\hline Chr* & Candidate gene & $\begin{array}{l}\text { Traits associated } \\
\text { gene }\end{array}$ & withBreed used & $\begin{array}{l}\text { Reference and country of } \\
\text { work }\end{array}$ \\
\hline & $\begin{array}{l}\text { Growth and differentiation factor } \\
9 \text { gene GDF9 }\end{array}$ & rLitter size, fecundity & $\begin{array}{l}\text { Barki, Ossimi, Rahmani and } \\
\text { Mehraban }\end{array}$ & $\begin{array}{l}\text { dBarakat et al., 2017; Talebi } \\
\text { et al., } 2018\end{array}$ \\
\hline \multirow[t]{3}{*}{6} & Kappa casein gene (CSN3) & $\begin{array}{l}\text { Milk production } \\
\text { composition }\end{array}$ & andAwassi & Jawasreh et al., 2019 \\
\hline & Alpha-S2-casein gene & Milk traits & Barki, Ossimi, and Rahmani & Othman et al., 2013 \\
\hline & $\begin{array}{l}\text { Bone morphogenetic } \\
\text { Protein receptor type } 1 \mathrm{~b} \text { gene } \\
\text { bmpr } 1 \mathrm{~b}\end{array}$ & $e^{\text {Litter size }}$ & Mehraban & Talebi et al., 2018 \\
\hline 7 & Ovine Calpain 3 gene & Growth traits & Barki, Rahmani and Ossimi & Mahrous et al., 2016 \\
\hline \multirow[t]{2}{*}{9} & $\begin{array}{l}\text { Fatty acid binding protein } 4 \text { gene } \\
\text { (FABP4) }\end{array}$ & eMeat quality & $\begin{array}{l}\text { Small tailed Han, Tan sheep } \\
\text { and Inner Mongolia }\end{array}$ & pXu et al., 2011 \\
\hline & $\begin{array}{l}\text { Diacylglycerol O-acyltransferase } \\
1 \text { gene DGAT1 }\end{array}$ & $\begin{array}{l}\text { eCarcass weight, dres } \\
\text { percentage }\end{array}$ & ssingMoghani & Noshahr and Rafat, 2014 \\
\hline \multirow[t]{4}{*}{11} & $\begin{array}{l}\text { Beta-1,4-N-acetylgalactosaminyl } \\
\text { Transferase } 2 \text { (B4GALNT2) }\end{array}$ & 1 Litter size & Mehraban & Talebi et al., 2018 \\
\hline & $\begin{array}{l}\text { Keratin gene (KRT 27, 31, } 36 \text {, } \\
38 \text { ) }\end{array}$ & 5.Wool traits & $\begin{array}{l}\text { Chinese Merino (Xinjiang } \\
\text { Type) }\end{array}$ & gSulayman et al., 2018 \\
\hline & Growth hormone gene $(\mathrm{GH})$ & Growth traits & Nilagiri & Cauveri et al., 2016 \\
\hline & KAP1.1 and KAP1.3 genes & Wool traits & $\begin{array}{l}\text { Barki, Rahmani, Ossimi and } \\
\text { Awassi }\end{array}$ & dFarag et al., 2018 \\
\hline 14 & $\begin{array}{l}\text { Ovine Hormone Sensitive Lipase } \\
\text { gene (HSL) }\end{array}$ & $\begin{array}{l}\text { eGrowth and body } \\
\text { composition }\end{array}$ & Sufflock & Yang, 2014 \\
\hline 16 & Follistatin gene (FST) & Wool quality & Chinese Merino & Ma et al., 2017a \\
\hline 18 & Callipyge gene (CLPG) & Meat production & Karnobat Merino & Dimitrova et al., 2017 \\
\hline 20 & Prolactin gene (PRL) & $\begin{array}{l}\text { Milk production } \\
\text { composition }\end{array}$ & andAwassi & Jawasreh et al., 2019 \\
\hline 22 & Dickkopf-1 gene (DKK1) & $\begin{array}{l}\text { Wool production } \\
\text { quality }\end{array}$ & andChinese Merino & Mu et al., 2017 \\
\hline \multirow[t]{2}{*}{26} & $\begin{array}{l}\text { Ovine Uncoupling Protein } 1 \text { gene } \\
\text { (UCP1) }\end{array}$ & eGrowth and carcass & Sufflock & Yang, 2014 \\
\hline & Ovine ADRB3 & $\begin{array}{l}\text { Growth and } \\
\text { composition }\end{array}$ & \multicolumn{2}{|c|}{ bodySufflock, Dorset, and Merino Yang, 2014; } \\
\hline $\mathbf{X}$ & $\begin{array}{l}\text { Bone morphogenetic protein } 15 \\
\text { gene (BMP15) }\end{array}$ & 5Litter size, fecundity & $\begin{array}{l}\text { Barki, Ossimi, Rahmani and } \\
\text { Mehraban }\end{array}$ & $\begin{array}{l}\text { dBarakat et al. } 2017 \text {; } \\
\text { Talebi et al., } 2018\end{array}$ \\
\hline
\end{tabular}

${ }^{*} \mathrm{Chr}=$ chromosome number.

Table 4. Candidate genes associated with economic traits in different breeds of goats as cited in literature

\begin{tabular}{|c|c|c|c|c|}
\hline Chr No & Candidate gene & $\begin{array}{l}\text { Traits associate } \\
\text { gene }\end{array}$ & d withBreed group used & $\begin{array}{l}\text { Reference and } \\
\text { country of work }\end{array}$ \\
\hline \multirow[t]{4}{*}{1} & $\begin{array}{l}\text { POU (Pit-Oct-Unc) class } \\
\text { homeobox } 1 \text { gene }(P O U 1 F 1)\end{array}$ & $\begin{array}{l}\text { 1Milk yield, } \\
\text { Litter size, } \\
\text { Body weight }\end{array}$ & $\begin{array}{l}\text { Inner Mongolia, W } \\
\text { Cashmere , Xinongsan } \\
\text { dairy, Laoshan da } \\
\text { Guanzhong dairy, Guiz } \\
\text { Black, Matou, Banjiao, } \\
\text { Guizhou White, Leizhou }\end{array}$ & $\begin{array}{l}\text { teLan et al., 2007, China } \\
\text { en } \\
\text { y, } \\
\text { ou }\end{array}$ \\
\hline & Somatostatin gene (SST) & Growth traits & $\begin{array}{l}\text { Boer, Chinese Xuhuai Wl } \\
\text { Chinese Haimen }\end{array}$ & e,Jin et al., 2011,China \\
\hline & $\begin{array}{l}\text { POU class } 1 \text { homeobox } 1 \text { g } \\
(\text { POU1F1) }\end{array}$ & $\begin{array}{l}\text { geneGrowth and } \\
\text { traits }\end{array}$ & carcassGuanzhong, Hainan black & $\begin{array}{l}\text { Ma et al., } 2017 \mathrm{~b}, \\
\text { China }\end{array}$ \\
\hline & & $\begin{array}{l}\text { Litter size, } \\
\text { Growth traits }\end{array}$ & Shaanbei White Cashmere & $\begin{array}{l}\text { Zhang et al., } 2019 \text {, } \\
\text { China }\end{array}$ \\
\hline \multirow[t]{2}{*}{2} & Myostatin gene (MSTN) & Body weights & $\begin{array}{l}\text { Mcluding Boer, } \\
\text {,Haimen, Nubi }\end{array}$ & $\begin{array}{l}\text { ouZhang et al., 2012a } \\
\text { China }\end{array}$ \\
\hline & & $\begin{array}{l}\text { Body weights } \\
\text { dimensions }\end{array}$ & andAnhui White, Boer & $\begin{array}{l}\text { Zhang et al., 2013, } \\
\text { China }\end{array}$ \\
\hline 4 & $\begin{array}{l}\text { Growth hormone-releasing horm } \\
\text { receptor gene } \\
\text { (GHRHR) }\end{array}$ & moneBody dimensions & $\begin{array}{l}\text { XinongSannen, } \\
\text { Guanzhong }\end{array}$ & Liu et al.,2011, China \\
\hline
\end{tabular}


Cont. Table 4. Candidate genes associated with economic traits in different breeds of goats as cited in literature

\begin{tabular}{|c|c|c|c|c|}
\hline Chr No & Candidate gene & $\begin{array}{l}\text { Traits associated witl } \\
\text { gene }\end{array}$ & hBreed group used & $\begin{array}{ll}\text { Reference } & \text { and } \\
\text { country of work }\end{array}$ \\
\hline & $\begin{array}{l}\text { Insulin like growth factor binding } \\
\text { protein } 3 \\
\text { gene (IGFBP-3) }\end{array}$ & gBody weights & Jamunapari & $\begin{array}{l}\text { Sharma et al., 2013, } \\
\text { India }\end{array}$ \\
\hline \multirow[t]{3}{*}{5} & $\begin{array}{l}\text { Insulin-like growth factor I gene } \\
\text { (IGF1) }\end{array}$ & eBody weights & Nanjiang Huang & $\begin{array}{l}\text { Zhang et al., 2008, } \\
\text { China }\end{array}$ \\
\hline & & $\begin{array}{l}\text { Milk yield, } \\
\text { Body size }\end{array}$ & Guanzhong, XinongSaanen & $\begin{array}{l}\text { Deng et al., 2010, } \\
\text { China }\end{array}$ \\
\hline & & Body weight & Jamunapari & $\begin{array}{l}\text { Sharma et al., 2013, } \\
\text { India }\end{array}$ \\
\hline \multirow[t]{2}{*}{7} & $\begin{array}{l}\text { PROP paired-like homeobox } 1 \text { gene } \\
(P R O P 1)\end{array}$ & $\begin{array}{l}\text { Growth and carcas } \\
\text { traits }\end{array}$ & sGuanzhong, Hainan Black & Ma et al., 2017, China \\
\hline & $\begin{array}{l}\text { Paired like homeodomain } 1 \text { gene } \\
\text { (PITX1) }\end{array}$ & $\begin{array}{l}\text { Growth and carcas } \\
\text { traits }\end{array}$ & sGuanzhong, Hainan Black & Ma et al., 2017, China \\
\hline 8 & Lipoprotein lipase gene (LPL) & $\begin{array}{l}\text { Milk yield } \\
\text { components }\end{array}$ & $\begin{array}{l}\text { dMajorera, Malaguen, } \\
\text { Saanen, Teramana, } \\
\text { Tinerfen, Palmera, } \\
\text { Alpine }\end{array}$ & $\begin{array}{l}\text { Badaoui et al., 2007b, } \\
\text { Spain }\end{array}$ \\
\hline 11 & $\begin{array}{l}\text { SIX homeobox } 3 \text { gene } \\
\text { (SIX3) }\end{array}$ & $\begin{array}{l}\text { Growth and carcas } \\
\text { traits }\end{array}$ & sGuanzhong, Hainan Black & Ma et al., 2017, China \\
\hline 15 & $\begin{array}{l}\text { Diacylglycerolacyltransferasegene } \\
(D G A T-2)\end{array}$ & Growth traits & $\begin{array}{l}\text { Boer, Chinese Xuhuai White, } \\
\text { Chinese Haimen }\end{array}$ & $\begin{array}{l}\text { Fang et al., 2012, } \\
\text { China }\end{array}$ \\
\hline 16 & $\begin{array}{l}\text { Methylenetetrahydrofolatereductase } \\
\text { gene } \\
(M T H F R)\end{array}$ & Milk production & $\begin{array}{l}\text { XinongSaanen, Guanzhong } \\
\text { dairy goats }\end{array}$ & $\begin{array}{l}\text { gAn et al., 2015b, } \\
\text { China }\end{array}$ \\
\hline \multirow[t]{8}{*}{19} & $\begin{array}{l}\text { Acetyl-CoA carboxylase-a gene } \\
\text { (ACACA) }\end{array}$ & eMilk production & $\begin{array}{l}\text { Saanen, Local Grey, } \\
\text { Syrian, Maltese, } \\
\text { Girgentana }\end{array}$ & $\begin{array}{l}\text { Federica et al., 2008, } \\
\text { Italy }\end{array}$ \\
\hline & $\begin{array}{l}\text { Acetyl-coenzyme A carboxylase } \\
\text { gene (ACACA) }\end{array}$ & $\alpha$ Milk production & Murciano- Granadina & $\begin{array}{l}\text { Badaoui et al., 2007a, } \\
\text { Spain }\end{array}$ \\
\hline & Growth hormone gene $(G H)$ & Growth traits & Boer goat & Hua et al., 2009, China \\
\hline & & $\begin{array}{l}\text { Milk production, Growt } \\
\text { traits }\end{array}$ & hJakhrana & $\begin{array}{l}\text { Gupta et al., 2009, } \\
\text { India }\end{array}$ \\
\hline & & Growth traits & Chinese & An et al., 2010, China \\
\hline & & Litter size & $\begin{array}{l}\text { Boer, } \\
\text { Matou }\end{array}$ & $\begin{array}{l}\text { Zhang et al., 2011, } \\
\text { China }\end{array}$ \\
\hline & & $\begin{array}{l}\text { Body weights } \\
\text { dimensions }\end{array}$ & $\begin{array}{l}\text { dBoer, } \\
\text { XinongSaanen }\end{array}$ & An et al., 2011, China \\
\hline & & Milk production & primiparousSarda & $\begin{array}{l}\text { Dettori et al., 2013, } \\
\text { Italy }\end{array}$ \\
\hline \multirow[t]{4}{*}{20} & $\begin{array}{l}\text { Growth hormone receptor gene } \\
\text { (GHR) }\end{array}$ & $\begin{array}{l}\text { eBody weights } \\
\text { dimensions }\end{array}$ & $\begin{array}{l}\text { dBoer, } \\
\text { XinongSaanen }\end{array}$ & An et al., 2011, China \\
\hline & & Body weight & Jamunapari & $\begin{array}{l}\text { Sharma et al., 2013, } \\
\text { India }\end{array}$ \\
\hline & $\begin{array}{l}\text { Prolactin receptor gene } \\
(P R L R)\end{array}$ & Milk production & $\begin{array}{l}\text { XinongSaanen, } \\
\text { Guanzhong }\end{array}$ & $\begin{array}{l}\text { Hou et al., 2013, } \\
\text { China }\end{array}$ \\
\hline & & Litter size & $\begin{array}{l}\text { Guanzhong, } \\
\text { Boer }\end{array}$ & An et al., 2015a, China \\
\hline 21 & $\begin{array}{l}\begin{array}{l}\text { Somatostatin } \\
\text { (SSTR1) }\end{array} \\
\text { Receptor } 1 \text { gene }\end{array}$ & eGrowth traits & $\begin{array}{l}\text { Boer goat, } \\
\text { Chinese Xuhuai } \\
\text { Chinese Haimen }\end{array}$ & Jin et al., 2011, China \\
\hline \multirow[t]{3}{*}{26} & $\begin{array}{l}\text { Stearoyl-CoA desaturase } \\
1 \text { gene }(S C D 1)\end{array}$ & Milk fatty composition & $\begin{array}{l}\text { Murciano- Granadina, } \\
\text { Malaguena breeds. }\end{array}$ & Zidi et al., 2010, Spain \\
\hline & $\begin{array}{ll}\text { Paired-like } & \text { homeodomain } \\
\text { transcription factor } 2 \text { gene }(P I T X 2)\end{array}$ & in Milk production & Guanzhong dairy goats & $\begin{array}{l}\text { Zhao et al., 2013, } \\
\text { China }\end{array}$ \\
\hline & $\begin{array}{l}\text { AT Motif-Binding Factor gene } \\
(A T B F 1)\end{array}$ & eGrowth traits & $\begin{array}{l}\text { Hainan Black, } \\
\text { XinongSaanen dairy goats }\end{array}$ & $\begin{array}{l}\text { Zhang et al., 2015, } \\
\text { China }\end{array}$ \\
\hline
\end{tabular}

\footnotetext{
${ }^{*} \mathrm{Chr}=$ chromosome number
} 
The concept of the associations in sheep could be summarized as follows:

(1) Genes located on chromosome 1: POU class 1 Homeobox 1 gene (PIT1) (Negahdary et al., 2014).

(2) Genes located on chromosome 2: Myostatin gene (MSTN) (Tellam et al., 2012; Dimitrova et al, .2017).

(3) Genes located on chromosome 3: Betalactoglobulin gene ( $\beta$-LG) (Jawasreh et al., 2019), Insulin like growth factor I gene (IGF-I) (Negahdary et al., 2014), Thyrotropin releasing hormone degrading enzyme gene TRHDE (Zhang et al., 2016), Keratin gene KRT81, 85 (Sulayman et al., 2018), alpha-lactalbumin gene (-LA; LALBA) (Giambra et al., 2014)

(4) Genes located on chromosome 4: Leptin gene (LEP) (Negahdary et al., 2014).

(5) Genes located on chromosome 5: Calpastatingene(Chung and Davis, 2012; Dimitrova et al. 2017), Myocyte enhancer factor 2B gene MEF2B (Zhang et al., 2016), Growth and differentiation factor 9 gene GDF9 (Barakat et al., 2017; Talebi et al., 2018).

(6) Genes located on chromosome 6: Kappa casein gene (CSN3) (Jawasreh et al., 2019), Alpha-S2casein gene (Othman et al., 2013), Bone morphogenetic Protein receptor type $1 \mathrm{~b}$ gene bmpr1b (Talebi et al., 2018).

(7) Genes located on chromosome 7: Ovine Calpain 3 gene (Mahrous et al., 2016).

(8) Genes located on chromosome 9: Fatty acid binding protein 4 gene (FABP4) (Xu et al., 2011), Diacylglycerol O-acyltransferase 1 gene DGAT1(Noshahr and Rafat, 2014).

(9) Genes located on chromosome 11: Beta-1,4-Nacetylgalactosaminyl Transferase 2 B4GALNT2 (Talebi et al., 2018), Keratin gene (KRT 27, 31, 36, 38) (Sulayman et al., 2018), Growth hormone gene GH (Cauveri et al., 2016), KAP1.1 and KAP1.3 genes (Farag et al., 2018).

(10) Genes located on chromosome 14: Ovine Hormone Sensitive Lipase gene (HSL) (Yang, 2014), Genes located on chromosome 16; Follistatin gene (FST) (Ma et al., 2017a).

(11) Genes located on chromosome 18: Callipyge gene CLPG (Dimitrova et al.2017).

(12) Genes located on chromosome 20: Prolactin gene (PRL) (Jawasreh et al., 2019).

(13) Genes located on chromosome 22: Dickkopf-1 gene (DKK1) (Mu et al., 2017).

(14) Genes located on chromosome 22: Ovine Uncoupling Protein 1 gene (UCP1), Ovine ADRB3 (Yang, 2014).

(15) Genes located on chromosome $\mathrm{x}$ : Bone morphogenetic protein 15 gene (BMP15) (Barakat et al. 2017; Talebi et al., 2018).

Also, the concept of the associations in goats could be summarized as follows:
(1) Genes located on chromosome 1: POU (Pit-OctUnc) class 1 homeobox 1 gene (POU1F1) (Lan et al., 2007), Somatostatin gene (SST) (Jin et al., 2011), POU class 1 homeobox 1 gene (POU1F1) (Ma et al., 2017b; Zhang et al., 2019).

(2) Genes located on chromosome 2: Myostatin gene (MSTN) (Zhang et al., 2012a, Zhang et al., 2013).

(3) Genes located on chromosome 4: Growth hormone-releasing hormone receptor gene (GHRHR) Liu et al. (2011), Insulin like growth factor binding protein 3 gene (IGFBP-3) (Sharma et al., 2013).

(4) Genes located on chromosome 5: Insulin-like growth factor I gene (IGF1) (Zhang et al., 2008; Deng et al., 2010; Sharma et al., 2013).

(5) Genes located on chromosome 7: PROP pairedlike homeobox 1 gene PROP1 gene, Paired like homeodomain 1 (PITX1) gene (Ma et al., 2017b).

(6) Genes located on chromosome 8: Lipoprotein lipase gene (LPL) (Badaoui et al., 2007b).

(7) Genes located on chromosome 11: SIX homeobox 3 gene (SIX3) (Ma et al., 2017b).

(8) Genes located on chromosome 16: Diacylglycerolacyltransferase gene (DGAT-2) (Federica et al., 2008), Genes located on chromosome 19: Acetyl-coenzyme A carboxylase $\alpha$ gene (ACACA) (Badaoui et al., 2007a), Growth hormone gene (GH) (Hua et al., 2009, Gupta et al., 2009, An et al., 2010, Dettori et al., 2013).

(9) Genes located on chromosome 20: Growth hormone receptor gene (GHR) (An et al., 2011), Prolactin receptor gene (PRLR) (Hou et al., 2013; An et al., 2015a).

(10) Genes located on chromosome 21: Somatostatin Receptor 1 gene (SSTR1) (Jin et al., 2011).

(11) Genes located on chromosome 26: Stearoyl-CoA desaturase 1 gene (SCD1) (Zidi et al., 2010), Paired-like homeodomain transcription factor 2 gene (PITX2) (Zhao et al., 2013), AT MotifBinding Factor gene (ATBF1) (Zhang et al., 2015).

\section{Identification of candidate genes in rabbits:}

Hull and Harvey (2000) recorded that growth hormone gene $(\mathrm{GH})$ is not classically considered as a reproductive hormone gene; although it has function, like: (1) it has great roles in reproductive function and secretion and action of $\mathrm{LH}$ and $\mathrm{FSH},(2)$ it is required for sexual differentiation and pubertal maturation, (3) it participates in gonadal steroid genesis, gametogenesis and ovulation, and (4) it required for fetal nutrition and growth during pregnancy and for mammary development and lactation. Several studies have shown significant associations with body weighs in rabbits (Fontanesi et al., 2008; Zhang et al., 2012b; Fontanesi et al., 2012; Peng et al., 2013; Sahwan et al., 2014; Wu et al., 2015; Othman et al., 2015; El-Aksher et al., 
2016; El-Sabrout and Aggag, 2017; Migdal et al., 2018).

In this concept, the following candidate genes in rabbits are considered:

1) Progesterone receptor gene (PGR) located on chromosome 1 (Peiró et al., 2008).

2) Fibroblast growth factor gene (FGF) located on chromosome 3 (El-Sabrout and Aggag, 2017).

3) Insulin-like growth factor 1 and 2 genes (IGF1and IGF2) located on chromosome 4 ((Fontanesi et al., 2012; El-Sabrout and Aggag, 2017).

Table 5. Candidate genes associated with

\begin{tabular}{|c|c|c|c|c|}
\hline \multirow{2}{*}{$\begin{array}{l}\text { Chr* } \\
1\end{array}$} & \multirow{2}{*}{$\begin{array}{l}\text { Candidate gene } \\
\text { Progesterone receptor gene }(P G R)\end{array}$} & \multicolumn{2}{|c|}{$\begin{array}{l}\text { Traits associatedBreed, line } \\
\text { with gene }\end{array}$} & \multirow{2}{*}{$\begin{array}{l}\begin{array}{l}\text { Reference and country } \\
\text { of work }\end{array} \\
\text { Peiró et al. 2008, Spain. }\end{array}$} \\
\hline & & Litter size & $\mathrm{H}$ and $\mathrm{L}$ lines & \\
\hline & & Body weight & V-line, Sinai Gabali & $\begin{array}{l}\text { El-Aksher et al. } \\
\text { 2016,Egypt }\end{array}$ \\
\hline 3 & Fibroblast growth factor gene $(F G F)$ & Body weight & V-line, Alexandria & $\begin{array}{l}\text { El-Sabrout and Aggag } \\
\text { 2017,Egypt }\end{array}$ \\
\hline \multirow[t]{2}{*}{4} & $\begin{array}{l}\text { Insulin-like Growth Factor } 1 \text { gene } \\
(I G F-1)\end{array}$ & eBody weight & V-line, Alexandria & $\begin{array}{l}\text { El-Sabrout and Aggag } \\
\text { 2017, Egypt }\end{array}$ \\
\hline & $\begin{array}{l}\text { Insulin-like growth factor } 2 \text { gene } \\
(I G F 2)\end{array}$ & Body weight & Different genetic groups & $\begin{array}{l}\text { Fontanesi } \quad \text { et } \\
\text { 2012,Italy }\end{array}$ \\
\hline \multirow[t]{5}{*}{7} & Myostatingene (MSTN) & Meat production & \multirow{2}{*}{\multicolumn{2}{|c|}{$\begin{array}{l}\text { Belgian Hare, BurgundyFontanesi et } \\
\text { Fawn, Checkered Giant, Giant2008, Italy } \\
\text { Grey } \\
\text { Z2 line, Z4 line, Z2×Z4 crossLu et al. 2011, China } \\
\text { line }\end{array}$}} \\
\hline & & Growth and Carcass & & \\
\hline & & Body weight & $\begin{array}{l}\text { Ira, Champagne, } \\
\text { Tianfu black }\end{array}$ & Peng et al. 2013, China \\
\hline & & Body weight & V-line, Alexandria & $\begin{array}{l}\text { El-Sabrout and Aggag } \\
\text { 2017,Egypt }\end{array}$ \\
\hline & Leptingene $(L E P)$ & $\begin{array}{l}\text { Carcass and me } \\
\text { quality }\end{array}$ & \multicolumn{2}{|c|}{ 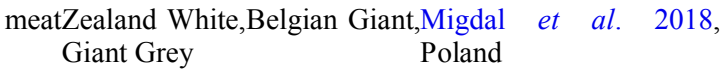 } \\
\hline 9 & Melanocortin 4 receptor gene $(M C 4 R)$ & Body weight & V-line, Alexandria & $\begin{array}{l}\text { El-Sabrout and Aggag } \\
\text { 2017, Egypt }\end{array}$ \\
\hline 10 & $\begin{array}{l}\text { Phosphorglyceratemutasegene } \\
(P G A M 2)\end{array}$ & Body weight & $\begin{array}{l}\text { Tianfublack,Ira, } \\
\text { Champagne }\end{array}$ & Wu et al. 2015, China \\
\hline \multirow[t]{4}{*}{11} & Growth hormone receptor gene $(G H R)$ & Body weight & $\begin{array}{l}\text { Tianfu black, Ira, } \\
\text { Champagne }\end{array}$ & Zhang et al. 2012, China \\
\hline & & Growth traits & $\begin{array}{l}\text { New Zealand White, } \\
\text { V-line, Californian, } \\
\text { Alexandria }\end{array}$ & $\begin{array}{l}\text { Sahwan et al. 2014, } \\
\text { Egypt }\end{array}$ \\
\hline & & Body weights & V-line, Alexandria & $\begin{array}{l}\text { El-Sabrout and Aggag } \\
2017 \text {,Egypt }\end{array}$ \\
\hline & Calpastatingene (CAST) & Meat quality & Champagne, Tianfu Black & Wang et al. 2016,China \\
\hline 12 & $\begin{array}{l}\text { Basic fibroblast growth factor gene } \\
(B F G F)\end{array}$ & eBody wrights & Japanese rabbits & Inoue et al. 2006, Japan. \\
\hline 14 & POU1F1 gene & Meat quality & $\begin{array}{l}\text { Hyla, Champagne, } \\
\text { Tianfu Black }\end{array}$ & Wang et al. 2015, China \\
\hline 15 & $\begin{array}{l}\text { Fibroblast growth factor } 5 \text { gene }(F G F-1 \\
\text { 5) }\end{array}$ & -Body weights & Local Egyptian & $\begin{array}{l}\text { Othman et al. 2015, } \\
\text { Egypt }\end{array}$ \\
\hline 18 & $\begin{array}{l}\text { Phosphorglyceratemutasegene } \\
(P G A M)\end{array}$ & Body weights & V-line, Alexandria & $\begin{array}{l}\text { El-Sabrout and Aggag } \\
\text { 2017,Egypt }\end{array}$ \\
\hline
\end{tabular}

4) Myostatin gene (MSTN) located on chromosome 7 (Fontanesi et al., 2012;; Peng et al., 2013).

5) Melanocortin 4 receptor gene (MC4R) located on chromosome 9 (El-Sabrout and Aggag, 2017).

6) Growth hormone receptor gene (GHR) located on chromosome 11.(Zhang et al., 2012b).

7) Growth hormone gene $(\mathrm{GH})$ located on chromosome 19 (Abdel-Kafy et al., 2016; ElSabrout and Aggag, 2017). 
Cont. Table 5. Candidate genes associated with economic traits in rabbits as cited in literature

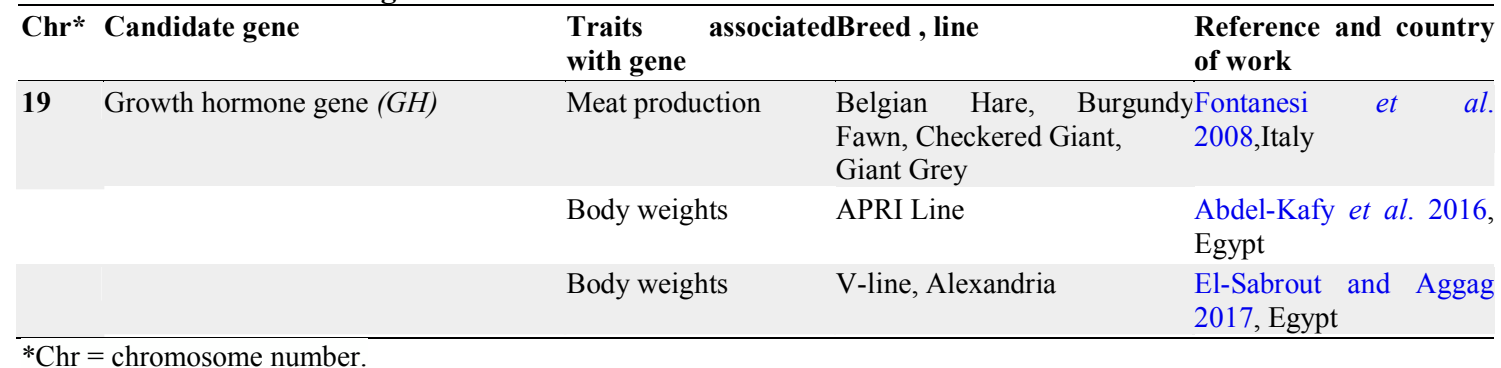

\section{Molecular characterization of candidate genes in livestock breeds:}

The candidate genes in local livestock breeds must be characterized for the following genetic parameters:

1) Allelic and genotypic frequencies and the genetic diversity of candidate genes to be assessed by calculating the effective number of alleles $(\mathrm{Ne})$, the observed $(\mathrm{Ho})$ and the expected $(\mathrm{He})$ heterozygosity using GENALEX software, version 6.5 (Peakall and Smouse, 2012):

2) Hardy-Weinberg equilibrium (HWE) within each population was estimated using GENEPOP program (Raymond, 1995); http://genepop.curtin.edu.au/) performing the Chisquare test for each genetic group studied.

3) The polymorphism information content (PIC) was calculated using CERVUS software, version 3 (Kalinowski et al., 2007):

4) The F-statistic of the reduction in heterozygosity due to inbreeding within each population (FIS) were calculated using GENEPOP software, version $\quad 3.4 \quad$ (Raymond, 1995); http://genepop.curtin.edu.au/).

\section{Bioinformatics sequencing and pairwise alignment of candidate genes:}

PCR products of candidate genes must be partially sequenced and registered Assessment of the genetic variability in the studied populations must be performed via identifying SNPs and gaps in F1 sequences and the parental sequences for all studied genes and SNPs. For example in an Egyptian poultry study (Saleh, 2019), the pairwise sequence alignment of gallinacin genes of the parents compared with F1 generation is illustrated in Figure 1 and Table 6.The high genetic variation considered was located in the regions associated with the innate immune response to bacteria (Sugiarto and $\mathrm{Yu}, 2004$;Higgs et al., 2005; Morammazi and Habibi, 2017)and having the role in increasing the resistance to diseases (BarShira and Friedman, 2006). For gallinacin-2 gene, a 583 bp product amplified from gallinacin 2 genomic DNA sequence had many substitution SNPs (Figure 1; Saleh, 2019): Seventeen SNPs were identified between Fayoumi and 1/2 Fayoumi 1/2Rhode Island with identity ratio of $97 \%$ and eleven SNP and three gaps with $1 / 2 \mathrm{R} 1 / 2 \mathrm{~F}$ with high identity percent of $98 \%$. Also, 12 SNPs were identified in Rhode Island with $1 / 2 \mathrm{~F}^{1} / 2 \mathrm{R}$ cross with identity ratio of $98 \%$ and 21 SNPs and one gap in $\mathrm{R}$ with $1 / 2 \mathrm{R} \frac{1}{2} \mathrm{~F}$ cross with high identity percent of $96 \%$.

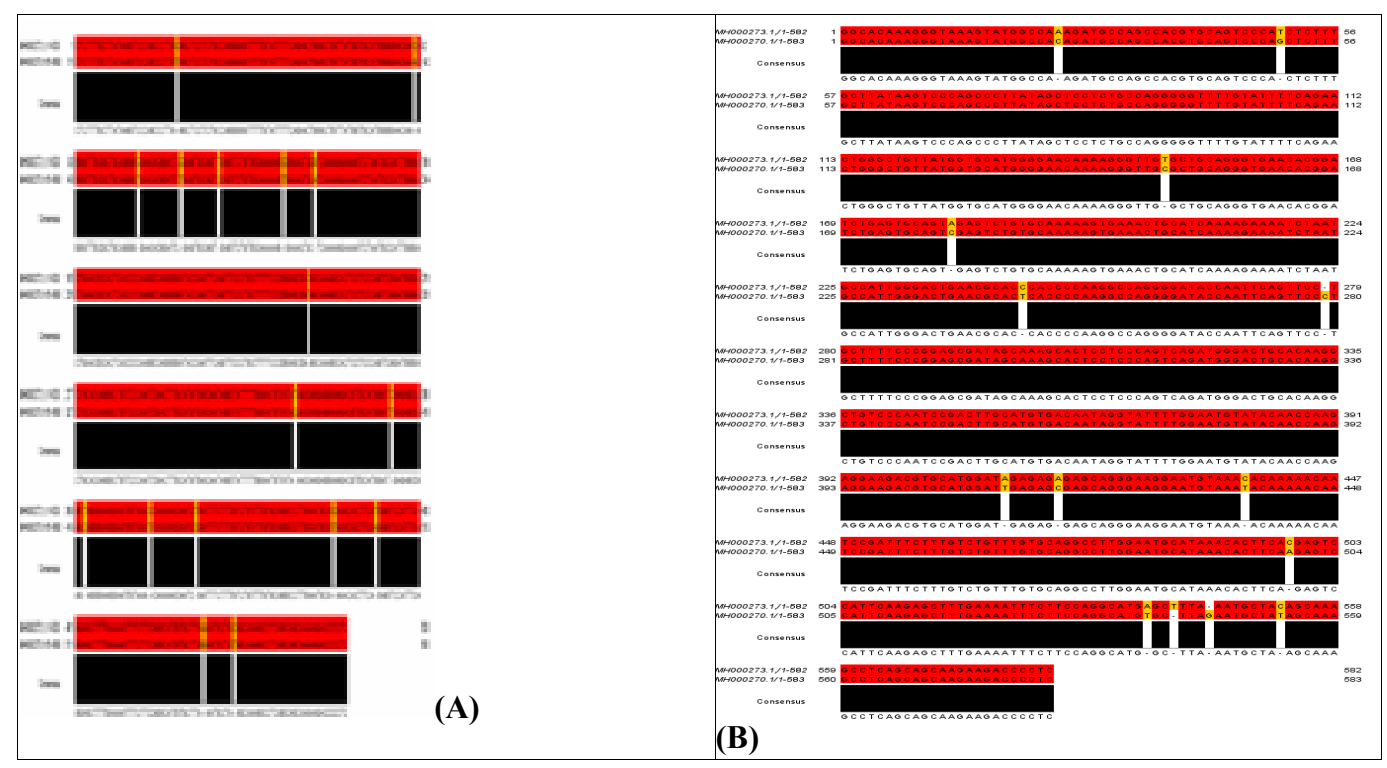




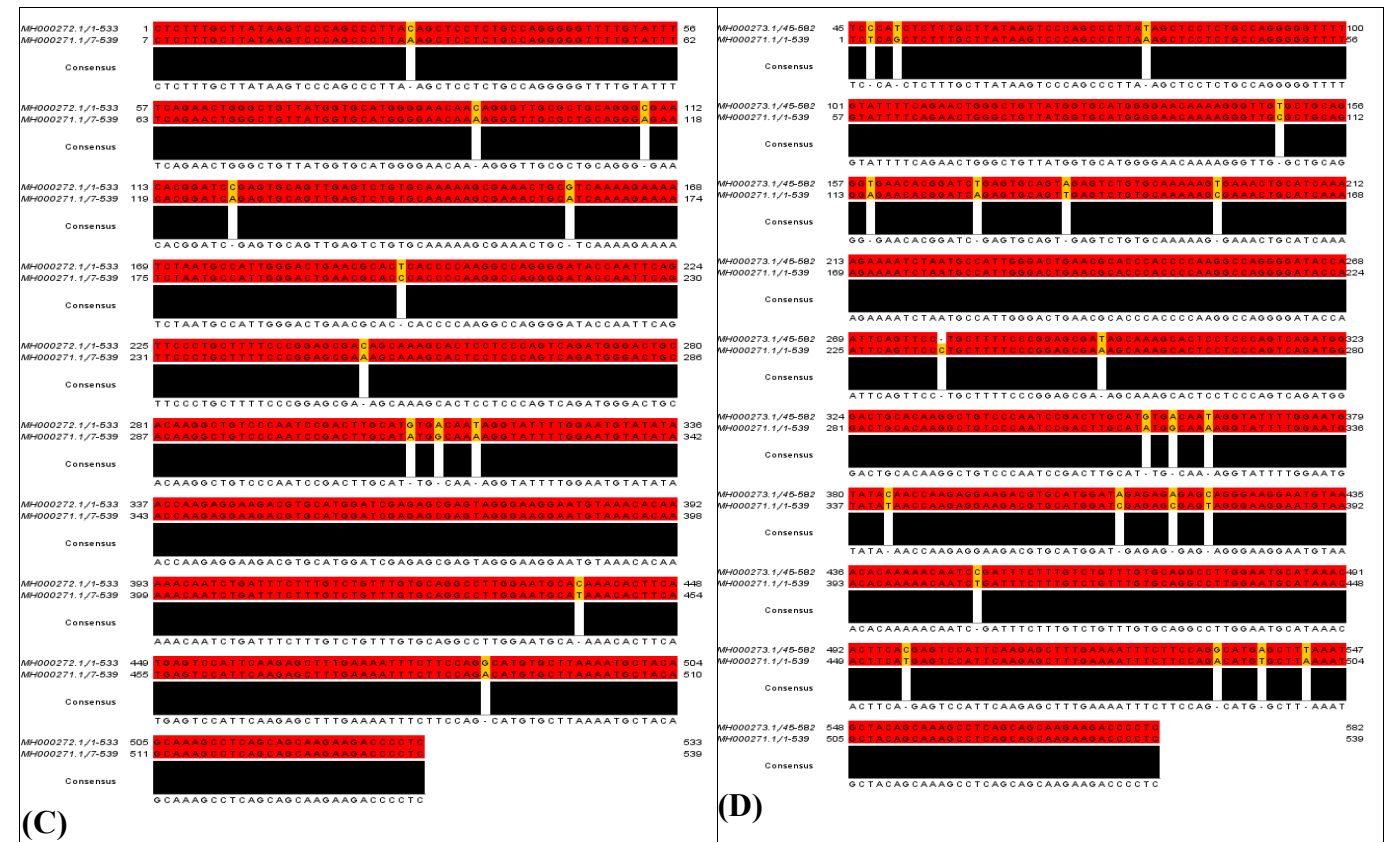

Figure 1: Pairwise sequence alignment of Gal 2 gene of the parents compared with $\mathrm{F} 1$ generation in chickens as cited by Saleh, 2019 ( set A: for F with $1 / 2 F^{1} / 2 R$ ), (set B: for F with $1 / 2 R^{1} / 2 F$ ), (set C: for $R$ with $1 / 2 F^{1} / 2 R$ ) and (set $D$ : for $\mathrm{R}$ with $\left.1 / 2 \mathrm{R} \frac{1}{2} \mathrm{~F}\right)$.

Table 6. Sequence of Gal 2 gene of the parents compared with F1 generation

\begin{tabular}{llll}
\hline Pairwise genetic groups & No. of SNPs & No. of gaps & Identity ratio (\%) \\
\hline Fayoumi with $1 / 2$ Fayoumi $1 / 2$ Rhode Island & 17 & - & 97 \\
Fayoumi with $1 / 2 \mathrm{R}^{1} / 2 \mathrm{~F}$ & 11 & 3 & 98 \\
Rhode Island with $1 / 2 \mathrm{~F}^{1} / 2 \mathrm{R}$ & 12 & - & 98 \\
Rhode Island with $1 / 2 \mathrm{R} \frac{1}{2} \mathrm{~F}$ & 21 & 1 & 96 \\
\hline
\end{tabular}

Polymorphism detection techniques (RAPD, AFLP and PCR-RFLP):

For animal genotyping, DNA polymorphisms are detected by varieties of techniques, the most common being randomly amplified polymorphic DNA (RAPD)(e.g. Nagy et al., 2010; Jawasreh et al., 2011; Qasim et al., 2011), single stranded conformation polymorphisms (SSCP) (e.g.Bastos et al., 2001), amplified fragment length polymorphisms (AFLP) by restriction fragment length polymorphisms (RFLP) (e.g.Abdel-rahman et al., 2010). These polymorphic procedures have been used for several purposes like genetic analysis of inbred strains, quantitative traits loci, variable number of tandem repeats (VNTR), microsatellites as short tandem repeats (STR), diversity analysis and single nucleotide polymorphisms SNP(e.g. Pariset et al., 2006). The Random Amplified Polymorphism DNA technique (RAPD) was invented as a genetic marker in 1990(Williams et al., 1990). The Amplified Fragment Length Polymorphism technique (AFLP) was originally described by Zabeau and Vos (1993). DNA polymorphisms may be detected in different ways, the most common being Restriction Fragment Length Polymorphism (RFLP). PCR-Restriction Fragment Length Polymorphism (PCR-RFLP) is a popular technique for genotyping which associated with the creation of a restriction enzyme recognition site (Narayanan, 1991). The more recently developed PCR-RFLP is an alternative method which takes the advantage of PCR techniques to enable more samples to be analyzed in a shorter time with very small amounts of DNA. However, Zaglol (2019) concluded that The PCR-RFLP technique is an appropriate tool for screening the genotypes of GHgene and for evaluating the genetic polymorphism in rabbit's breeds.

The PCR-RFLP consists of two main steps: first, amplifying DNA using the standard PCR (i.e. amplification), second, digesting PCR product using restriction enzymes (i.e. Digestion). Hailu and Getu (2015) stated that the most important advantages of the PCR-RFLP technique include: 1) it was widely applied for the analysis of genetically determined diseases, 2) inexpensiveness and lack of requirements for advanced instruments, 3) it has easy design and can be accomplished using public available programs, 4) RFLP is labor-intensive and timeconsuming, 5) it can be used to check out only specific mutations at enzyme cut sites, 6) detecting the polymorphism is relatively low, 7) it has high reliability, because it is generated from specific sites via known restriction enzymes and the results are constant over time and location, and 8) it can be used to detect the oncogenes in gene mapping and phylogenetic analysis and for the study of association 
relations of candidate genes with performance traits. The disadvantages of the PCR-RFLP method as stated by Rasmussen (2012) include: 1) it requires specific endonucleases in identifying the exact variation, and 2) it requires several SNP in affecting the same restriction enzyme recognition site.

Model for detecting the molecular associations between genotypes of candidate gene and economic traits:

To detect the molecular associations between the genotypes of $G H$ candidate gene and economic traits, the effects of SNP genotype on different traits to be estimated using PEST software(Groeneveld, 2006) and applying the following multi-trait animal model (defined in matrix notation):

$\mathrm{y}=\mathrm{Xb}+\mathrm{Zaua}+\mathrm{e}$

Where $y=$ vector of observed trait the animal; $b=$ vector of fixed effects, the $i^{\text {th }}$ genotype of GH gene (three genotypes); $\mathrm{X}$ and $\mathrm{Za}=$ incidence matrices corresponding to the fixed and additive random effects of the animal (ua), respectively; $\mathrm{e}=$ vector of random residual effects.

\section{Molecular associations between candidate genes and economic traits in livestock:}

In molecular study in Egypt, Mohamed (2019) concluded that: 1) the lactoferrin and prolactin genes could be considered as the essential major genes for milk yield and components in dairy cattle, 2) The strong associations among genotypes of prolactin and lactoferrin genes and milk yield traits could be used as a powerful tool in selection, 3), In Elkarada Friesian herd, we can select towards $\mathrm{AA}$ and $\mathrm{AB}$ genotypes for lactoferrin gene in Friesian cattle in Egypt, 4) For prolactin gene in Friesian Sakha and Elkarada herds, the CD genotype was the highest genotype in milk and protein yields taking into account Nael as restriction enzyme so this genotype must be the main target in selection, 5) in other local Baladi herds, the generalized least square means for
GGGT, and TT genotypes groups were 724, 294 and 584 kilogram of milk yield, respectively and the differences among the three genotypes in milk, fat and protein yields were not significant.

Abdel-Kafy et al. (2016) estimated the association between the $G H \mathrm{C}>\mathrm{T}$ SNP with body weight, growth and reproductive traits in rabbit populations and reported that: (1) heterozygote genotype (T/C) was significantly associated with heavy weight of rabbits at 8 weeks and daily gain through 5-8 week interval compared to TT and CC genotypes $(\mathrm{P}<0.05)$, (2) The polymorphism of growth hormone gene $(G H)$ in rabbits may has overdominance at the locus c.-78C $>\mathrm{T}$, and (3) Positive effects of the heterozygous genotype were recorded compared to both homozygous genotypes on body weights and body gains, i.e. the heterozygous genotype in c.-78C $>\mathrm{T}$ of $G H$ polymorphisms could be used as a favorable genotype in rabbits and may be used in the Marker-assisted selection (MAS) programs to improve growth performance. Zaghloul (2019) stated that there were significant associations between $G H$ gene and growth traits and this confirmed the fact that this gene could be used as a candidate gene as Marker-assisted selection in genetic improvement programs (MAS) to improve growth performance in rabbits and enhance the semen traits in the Egyptian rabbits.

Suggested genetic improvement program in the Egyptian cattle using molecular approaches:

Using traditional selection for genetic improvement of farm animals will cause slow and low genetic progress and using biotechnology techniques are the best way to achieve fast genetic improvement. The list of the necessary steps to perform a genetic improvement program in the Egyptian farm animals using the molecular applications could be summarized as follows:

\footnotetext{
Step No Procedure and Executable Approach

1 Determining the main objectives:

1) To use the molecular information using genome-wide association approach to detect quantitative trait loci associated with some economic traits and use the significant QTLs in marker assisted selection.

2) To estimate the genomic breeding values (GBV) and their reliabilities for the genotyped animals and select the best cows and bulls in cattle based on their GBV to be parents for the next generation (genomic selection).

3) To use the semen of the best evaluated sires with the highest GBVs (proven sires) in the artificial insemination of the best evaluated cows and recording the same productive and reproductive traits on the resulted progeny.

2 Collecting and recording the phenotypic data to get the full pedigree file for all animals (cows and bulls).: Not adequate records must be discarded to ensure a homogenous data set. Adequate number of animals (e.g. 445 cows and 55 bulls) will be used. Pedigreed animals will be used to estimate the breeding value of the animals for the studied traits.

$3 \quad$ Evaluating the animals genetically:

The genetic evaluation of animals will be carried out using a univariate animal model using the BLUPF90 software (Misztal et al., 2002). The breeding value will be estimated by an animal model using BLUPF90 software (Misztal et al., 2014) fitting univariate approach. The assumed model was: $\mathbf{y}=\mathbf{X b}+\mathbf{Z a}+\mathbf{e}$ where, $y=$ vector of observations, $b=$ vector of fixed effects with an incidence matrix $X, a=$ vector of random animal effects with incidence matrix $\mathrm{Z}$, and $\mathrm{e}=$ vector of random residual effects

4 Determine the list of main equipments required and the main list of chemicals for DNA extraction: The necessary equipments chemicals are: PCR machine, Real-time PCR, Gel electrophoresis, Gel Documentation
} 
System, Vortex, Centrifuge 30000 rpm under cooling, Biosafety cabinet,EDTA, Ethidium Bromide, Magnesium chloride, dNTPs, PCR Master Mix (2X), Sybr green master mix kits, PFU Taq DNA Polymerase, Agarose, Phenol (nucleic acid grade), DNA isolation Kit from animal tissues, Micropipettes set, Eppendorf.

The blood samples will be collected under sterile conditions by jugular vein puncture using 5-ml vacuum tubes of polypropylene containing EDTA. The samples will transfer to the laboratory in iceboxes containing ice packs and stored at $-20^{\circ} \mathrm{C}$ until extract the genomic DNA. Genomic DNA extraction: genomic DNA will extract using a standard phenol-chloroform extraction protocol and ethanol precipitation methods (Sambrook, 1989).

$6 \quad$ Genotyping the animals:

The animals will be genotyped using SNPs markers.

$7 \quad$ Applying the bioinformatics analyses for candidate genes and detecting QTLs:

For bovine genome, a list of previously reported QTL for the traits was obtained from animal QTL db, release 30 (Hu et al., 2016) (http://www.animalgenome.org/QTLdb).

$8 \quad$ Preparing and editing the genotyping files (Nicolazzi et al., 2014): Significantly markers $(\mathrm{P}<0.001)$ not deviated from Hardy-Weinberg proportion were used.

$9 \quad$ Estimating the average yield deviation for each trait:

The yield deviation for each animal will be estimated using a mixed model procedure implemented in SAS software, version 9.4 (SAS 2014, SAS Institute Inc., Cary, NC, USA).

This step will be performed using the linear regression model as implemented in PLINK software (Purcell et al., 2007), where the average daily deviations will be regressed on the number of copies of the alleles using the PLINK software.

The animals with more than $20 \%$ missing marker genotype will excluded from the analysis. An SNP will be removed from the analysis if it had minor allele frequency less than $2 \%$, call rate less than $90 \%$ and exhibiting deviation from Hardy-Weinberg equilibrium (HWE) with $\mathrm{P}<10-6$. Filtration of the marker data was performed with Plink software (Purcell et al. 2007). A genome wide association analysis will performed using linear regression model in the way of SNP-by-SNP, though, regressing the average daily deviations on SNP alleles and will be implemented by Plink software. The PLINK software that will be used for analyzing the GWAS using the following model:

$\mathbf{y}=\mathbf{x b}+\mathbf{e}$

Where, $\mathrm{y}$ is a vector of each GBVs of the genotyped individuals, $\mathrm{x}$ is each SNP information and $\mathrm{b}$ is coefficient value for $\mathrm{x}$ vector.

11 Applying SNP association test:

We will use genomic control p-value instead of normal p-value to search for the genes closely associated with economic traits, the National Center for Biotechnology Information (NCBI) database will be used.

12 Applying genome-wide complex trait analysis (GCTA):

The software v1.25.3 will be used to estimate the heritability of the average yield deviation (Yang et al., 2011).

13 Estimating the genomic breeding values (GBV) to be applied in genomic selection:

The genomic breeding values (GBV) will be estimated as the sum of the effects of dense genetic markers, or haplotypes of these markers, across the entire genome capturing all the quantitative trait loci (QTL) that contribute to variation in a trait. The QTL effects, inferred from individual single nucleotide polymorphism (SNP) markers, are first estimated in a large reference population with phenotypic information. In subsequent generations or in related populations, only marker information is required to calculate GEBV.

$14 \quad$ Evaluating the prediction accuracy (EBV vs GEBV) :

The correlation between the estimated traditional breeding values (EBV; using phenotypic data and pedigree) and the genomic breeding values (GBV)must be estimated, as well as the reliability of the two breeding values. Both the reliability of GEBV and the correlation between EBV and GEBV were used to evaluate the prediction accuracy (Moser et al., 2009).

15 Estimating the Genomic Best Linear Unbiased Predictions (GBLUP) and SNP-GBLUP:

The mixed model will be used to estimate the breeding values include BLUP and best linear unbiased estimation. These models estimate the fixed effects such as sex and predict the random effects such as SNPs for a given quantitative phenotype. The proposed mixed model and its solution are presented as follows:

$\mathbf{y}=\mathbf{X b}+\mathbf{Z u}+\mathbf{e}$

Where $\mathrm{y}$ is the vector of phenotypic values, $\mathrm{X}$ and $\mathrm{Z}$ are the design matrices; $\mathrm{b}$ and $\mathrm{u}$ are vectors of fixed and random effects, respectively. To compare the estimated breeding values (EBV) of the total SNPs with trimmed SNPs (unadjusted cutoff p-value 0.01), we will use the G-BLUP which adopts the genomic relationship matrix (GRM) with total pruned SNPs and SNP-GBLUP which utilizes the SNP-SNP relationship matrix with trimmed SNPs (Lee et al., 2014).

16 Estimating the genomic breeding values (GBV) to be applied in genomic selection (GS):

The genomic breeding values (GBV) and their reliabilities for the genotyped animals will be used to select the best cows and bulls based on their GBV to be parents for the next generation (genomic selection).

The genomic selection (GS) is a form of marker assisted selection in which genetic markers covering the whole genome are used so that all quantitative trait loci (QTL) are in linkage disequilibrium with at least one marker. This approach has become feasible due to revolution in SNP discovery method like deep sequencing and throughput SNP genotyping on DNA chip. 


\section{REFERENCES}

Abdel-Kafy, E., Darwish, S. and Elkhishin, D. 2016. Correlating single nucleotide polymorphisms in the myostatin gene with performance traits in rabbit. World Rabbit Science, 24, 213-221.

Abdel-Rahman, S. M., Sugita, T., González, G. M., Ellis, D., Arabatzis, M., Vella-Zahra, L., ViguieVallanet, C., Hiruma, M., Leeder, J. S. andPreuett, B. 2010. Divergence among an international population of Trichophyton tonsurans isolates. Mycopathologia, 169, 1-13.

Abo-Al-Ela, H. G., El-Magd, M. A., El-Nahas, A. F. and Mansour, A. A. 2014. Association of a novel SNP in exon 10 of the IGF2 gene with growth traits in Egyptian water buffalo (Bubalus bubalis). Tropical Animal Health and Production, 46, 947952.

An, X., Hou, J., Wang, L., Li, G., Wang, J., Song, Y., Zhou, G., Han, D., Ling, L. and Cao, B. 2010. Novel polymorphisms of the growth hormone gene and their effect on growth traits in Chinese goats. Meat Science, 86, 758-763.

An, X., Wang, L., Hou, J., Li, G., Song, Y., Wang, J., Yang, M., Cui, Y. and Cao, B. 2011. Novel polymorphisms of goat growth hormone and growth hormone receptor genes and their effects on growth traits. Molecular Biology Reports, 38, 4037-4043.

An, X., Hou, J., Gao, T., Lei, Y., Li, G., Song, Y., Wang, J. and Cao, B. 2015a. Single-nucleotide polymorphisms g. $151435 \mathrm{C}>\mathrm{T}$ and g. $173057 \mathrm{~T}>$ $\mathrm{C}$ in PRLR gene regulated by bta-miR-302a are associated with litter size in goats. Theriogenology, 83, 1477-1483. e1.

An, X., Song, Y., Hou, J., Han, P., Peng, J., Zhang, L., Wang, J. and Cao, B. 2015b. Mutations in the MTHFR gene and their associations with milk production traits in dairy goats. Small Ruminant Research, 130, 76-80.

Andersson, L. 2001. Genetic dissection of phenotypic diversity in farm animals. Nature Reviews Genetics, 2, 130-138.

Anton, I., Kovács, K., Fesus, L., Várhegyi, J., Lehel, L., Hajda, Z., Polgar, J., Szabó, F. and Zsolnai, A. 2008. Effect of DGAT1 and TG gene polymorphisms on intramuscular fat and on milk production traits in different cattle breeds in Hungary. Acta Veterinaria Hungarica, 56, 181186.

Araújo, D. N., De Camargo, G. M. F., Fonseca, P. D. D. S., Cardoso, D. F., Hurtado-Lugo, N. A., Aspilcueta-Borquis, R. R. and Tonhati, H. 2015. Polymorphisms in Oxytocin and $\alpha 1$ a Adrenergic Receptor Genes and their effects on production traits in dairy buffaloes. Animal Biotechnology, 26, 165-168.

Aziz, M.A. Schoeman, S.J. Jordaan, G.F. ElChafie O.M. and Mahdy A.T. 2001. Genetic and phenotypic variation of some reproductive traits in Egyptian buffalo. South African Journal of Animal Science, 31(3):195-201.

Badaoui, B., Serradilla, J., Tomas, A., Urrutia, B., Ares, J., Carrizosa, J., Sanchez, A., Jordana, J. and Amills, M. 2007a. Goat acetyl-coenzyme A carboxylase $\alpha$ : Molecular characterization, polymorphism, and association with milk traits. Journal of Dairy Science, 90, 1039-1043.

Badaoui, B., Serradilla, J., Tomas, A., Urrutia, B., Ares, J., Carrizosa, J., Sanchez, A., Jordana, J. and Amills, M. 2007b. Identification of two polymorphisms in the goat lipoprotein lipase gene and their association with milk production traits. Journal of Dairy Science, 90, 3012-3017.

Baena, M. M., Tizioto, P. C., Meirelles, S. L. C. and Regitano, L. C. D. A. 2018. HSF1 and HSPA6 as functional candidate genes associated with heat tolerance in Angus cattle. Revista Brasileira de Zootecnia, 47.

Baiomy, A. A. 2012.Studies of some factors influencing milk production of Egyptian buffaloes in Upper Egypt. Alexandria Journal of Agricultural Research 57(3): 257-262.

Barakat, I. A., Salem, L. M., Daoud, N. M., Khalil, W. K. and Mahrous, K. F. 2017. Genetic polymorphism of candidate genes for fecundity traits in Egyptian sheep breeds. Biomedical Research, 28, 851-857.

Barbosa, E., Souza, B., Guimarães, R., Azevedo, J., Goncalves, E., Ribeiro, H., Filho, S. R. and Filho, E. S. 2016. Polymorphism in the melatonin receptor gene in buffalo populations of the Brazilian Amazon. Genet. Mol. Res, 15.

Bar-Shira, E. andFriedman, A. 2006. Development and adaptations of innate immunity in the gastrointestinal tract of the newly hatched chick. Developmental andComparative Immunology, 30, 930-941.

Bastos, E., Cravador, A., Azevedo, J. and GuedesPinto, H. 2001. Single strand conformation polymorphism (SSCP) detection in six genes in Portuguese indigenous sheep breed'Churra da Terra Quente'. Biotechnologie, Agronomie, Société et Environnement, 5, 7-15.

Brown, S. M. 1999. Snapping Up SNPs. BioTechniques, 26, 1090-1093.

Brym, P., Kamiński, S. andWójcik, E. 2005. Nucleotide sequence polymorphism within exon 4 of the bovine prolactin gene and its associations with milk performance traits. Journal of Applied Genetics, 46, 179-185.

Buchanan, F., Thue, T., Yu, P. and Winkelman-Sim, D. 2005. Single nucleotide polymorphisms in the corticotrophin-releasing hormone and pro-opiomelancortin genes are associated with growth and carcass yield in beef cattle. Animal Genetics, 36, 127-131. 
Bulut, Z., Kurar, E., Ozsensoy, Y., Nizamlioglu, M., Garip, M., Yilmaz, A., Caglayan, T., Dere, S., Kurtoglu, V. andDogan, M. 2013. Determination of chromosomal regions affecting body weight and egg production in Denizli X White Leghorn F2 populations. Eurasian Journal of Veterinary Sciences, 29, 30-38.

Casas, E., Bennett, G., Smith, T. and Cundiff, L. 2004. Association of myostatin on early calf mortality, growth, and carcass composition traits in crossbred cattle. Journal of Animal Science, 82, 2913-2918.

Casas, E., White, S., Wheeler, T., Shackelford, S., Koohmaraie, M., Riley, D., Chase Jr, C., Johnson, D. and Smith, T. 2006. Effects of calpastatin and $\mu$-calpain markers in beef cattle on tenderness traits. Journal of Animal Science, 84, 520-525.

Cauveri, D., Sivaselvam, S., Karthickeyan, S., Tirumurugaan, K., Kumanan, K. and Venkataramanan, R. 2016. Single nucleotide polymorphisms in $\mathrm{GH}$ (growth hormone) gene associated with growth traits in Nilagiri sheep of Tamil Nadu. International Journal of Science, Environment and Technology, 5, 4097-4103.

Chung, H. and Davis, M. 2012. PCR-RFLP of the ovine calpastatin gene and its association with growth. Asian J Anim Vet Adv, 7, 641-652.

Cobanoglu, O., Zaitoun, I., Chang, Y., Shook, G. and Khatib, H. 2006. Effects of the signal transducer and activator of transcription 1 (STAT1) gene on milk production traits in Holstein dairy cattle. Journal of Dairy Science, 89, 4433-4437.

Cosenza, G., Macciotta, N. P., Nudda, A., Coletta, A., Ramunno, L. and Pauciullo, A. 2017. A novel polymorphism in the oxytocin receptor encoding gene (OXTR) affects milk fatty acid composition in Italian Mediterranean river buffalo. Journal of Dairy Research, 84, 170-180.

Datta, S., Adikari, A., Chauhan, A., Verma, A., Gupta, I., Chauhan, I., Azad, M. S. and Hm, Y. 2012. Nucleotide sequence variation in leptin gene of Murrah buffalo (Bubalus bubalis). Exper Anim Med Res, 2, 130-136.

De Roos, A., Schrooten, C., Veerkamp, R. andVan Arendonk, J. 2011. Effects of genomic selection on genetic improvement, inbreeding, and merit of young versus proven bulls. Journal of Dairy Science, 94, 1559-1567.

Dekkers, J. C. M. 2007. Prediction of response to marker-assisted and genomic selection using selection index theory. Journal of Animal Breeding and Genetics, 124(6), 331-341.

Deng, C., Ma, R., Yue, X., Lan, X., Chen, H. and Lei, C. 2010. Association of IGF-I gene polymorphisms with milk yield and body size in Chinese dairy goats. Genetics and Molecular Biology, 33, 266-270.

Deng, T., Pang, C., Zhu, P., Liao, B., Zhang, M., Yang, B. and Liang, X. 2015. Molecular cloning and expression analysis of the STAT1 gene in the water buffalo (Bubalus bubalis). Tropical Animal Health and Production, 47, 53-59.

Deng, T., Pang, C., Liu, M., Zhang, C. and Liang, X. 2016. Synonymous single nucleotide polymorphisms in the MC4R gene that are significantly associated with milk production traits in water buffaloes. J. Gen. Mol. Res, 15, 1-8

Deepika and Salar, R. 2014. Polymorphism studies of prolactin receptor (PRLR) gene in indigenous grey cattle breeds of India. Double Helix Research-International Journal of Biomedical and Life Sciences, 5, 314-321.

Dettori, M. L., Rocchigiani, A. M., Luridiana, S., Mura, M. C., Carcangiu, V., Pazzola, M. and Vacca, G. M. 2013. Growth hormone gene variability and its effects on milk traits in primiparous Sarda goats. Journal of Dairy Research, 80, 255-262.

Dimitrova, I., Bozhilova-Sakova, M. and Iliev, M. 2017. Study of some genes associated with meat productivity in Karnobat Merino sheep breed using PCR-RFLP. IOSR Journal of Agriculture and Veterinary Science, 10 (8 Ver. III): 61-65

Dybus, A., Grzesiak, W., Kamieniecki, H., Szatkowska, I., Sobek, Z., Błaszczyk, P., Czerniawska-Piątkowska, E., Zych, S. andMuszyńska, M. 2005. Association of genetic variants of bovine prolactin with milk production traits of Black-and-White and Jersey cattle. Archives Animal Breeding, 48, 149-156.

El-Aksher, S. H., Sherif, H., Khalil, M., El-Garhy, H. A. and Ramadan, S. 2016. Polymorphism of progesterone receptor gene in Moshtohor line rabbits and their parental lines using PCR-RFLP technique. $3 r d$ International Conference on Biotechnology Applications in Agriculture (ICBAA), Benha University, Moshtohor and Sharm El-Sheikh, 5-9 April 2016, Egypt.

El-Magd, M., Abbas, H., El-Kattawy, A. and Mokhbatly, A. 2013. Novel polymorphisms of the IGF1R gene and their association with average daily gain in Egyptian buffalo (Bubalus bubalis). Domestic Animal Endocrinology, 45, 105-110.

El-Magd, M. A., Abo-Al-Ela, H. G., El-Nahas, A., Saleh, A. A. and Mansour, A. A. 2014. Effects of a novel SNP of IGF2R gene on growth traits and expression rate of IGF2R and IGF2 genes in gluteus medius muscle of Egyptian buffalo. Gene, 540, 133-139.

El-Sabrout, K. and Aggag, S. 2017. The gene expression of weaning age and its effect on productive performance of rabbits. World Rabbit Science, 25, 1-7.

Erhardt, G. andWeimann, C. 2007. Use of molecular markers for evaluation of genetic diversity and in animal production. Arch. Latinoam. Production Animal. 15, 63-66.

FAO. 2011. Molecular genetic characterization of animal genetic resources. FAO Animal Production and Health Guidelines. No. 9. Rome.

Fan, H., Wu, Y., Zhou, X., Xia, J., Zhang, W., Song, Y., Liu, F., Chen, Y., Zhang, L. andGao, X. 2015. 
Pathway-based genome-wide association studies for two meat production traits in Simmental cattle. Scientific Reports, 5, 18389-18396.

Fang, X., Zhang, J., Xu, H., Zhang, C., Du, Y., Shi, X., Chen, D., Sun, J., Jin, Q. and Lan, X. 2012. Polymorphisms of diacylglycerol acyltransferase 2 gene and their relationship with growth traits in goats. Molecular Biology Reports, 39, 1801-1807.

Farag, I. M., Darwish, H. R., Darwish, A. M., Eshak, M. G. and Ahmed, R. W. 2018. Genetic golymorphism of KRT1. 2 gene and its association with improving of some wool characteristics in Egyptian sheep. Asian Journal of Scientific Research, 11, 295-300.

Fatima, S., Bhatt, S., Bhong, C., Rank, D. and Joshi, C. 2009. Genetic polymorphism study of IGF-I gene in buffaloes of Gujarat. Buffalo Bull, 28, 159-164.

Federica, S., Francesco, N., Giovanna, D. M., Carmela, S. M., Gennaro, C., Carmela, T. and Bianca, M. 2008. Identification of novel single nucleotide polymorphisms in promoter III of the acetyl-CoA carboxylase- $\alpha$ gene in goats affecting milk production traits. Journal of Heredity, 100, 386-389.

Fontanesi, L., Scotti, E., Tazzoli, M., Beretti, F., Dall'olio, S., Davoli, R. and Russo, V. 2007. Investigation of allele frequencies of the growth hormone receptor (GHR), F279Y mutation in dairy and dual purpose cattle breeds. Italian Journal of Animal Science, 6, 415-420.

Fontanesi, L., Tazzoli, M., Scotti, E. and Russo, V. 2008. Analysis of candidate genes for meat production traits in domestic rabbit breeds. Proceedings of the 9th World Rabbit Congress, Verona, Italy, 10-13 June 2008, World Rabbit Science Association, 79-84.

Fontanesi, L., Tazzoli, M., Russo, V. and Beever, J. 2010. Genetic heterogeneity at the bovine KIT gene in cattle breeds carrying different putative alleles at the spotting locus. Animal Genetics, 41, 295-303.

Fontanesi, L., Dall'olio, S., Spaccapaniccia, E., Scotti, E., Fornasini, D., Frabetti, A. and Russo, V. 2012. A single nucleotide polymorphism in the rabbit growth hormone (GH1) gene is associated with market weight in a commercial rabbit population. Livestock Science, 147, 84-88.

Fontanesi, L., Calò, D., Galimberti, G., Negrini, R., Marino, R., Nardone, A., Ajmone-Marsan, P. and Russo, V. 2014. A candidate gene association study for nine economically important traits in Italian Holstein cattle. Animal Genetics, 45, 576580.

Fontanesi, L., Scotti, E., Samore, A., Bagnato, A. and Russo, V. 2015. Association of 20 candidate gene markers with milk production and composition traits in sires of Reggiana breed, a local dairy cattle population. Livestock Science, 176, 14-21.
Freitas, A., De Camargo, G., Aspilcueta-Borquis, R., Stafuzza, N., Venturini, G., Tanamati, F., Hurtado-Lugo, N., Barros, C. and Tonhati, H. 2016. Polymorphism in the A2M gene associated with high-quality milk in Murrah buffaloes (Bubalus bubalis). Genetics and Molecular Research: GMR, 15

Giambra, I., Brandt, H. and Erhardt, G. 2014. Milk protein variants are highly associated with milk performance traits in East Friesian Dairy and Lacaune sheep. Small Ruminant Research, 121, 382-394.

Gollapudi, A. S. B. 2003. Molecular variants of bovine $\mathrm{GH}$ and GHR and their association with milk production traits in Canadian Holstein bulls. M.Sc. thesis, Department of Animal Science, McGill University, Montreal, Quebec, Canada

Gregerson, K. A. 2006. Prolactin: structure, function and regulation of secretion. Knobil and Neill's Physiology of Reproduction, 1, 1703-1726.

Groeneveld, E. 2006. PEST User's Manual. Institute of Animal Husbandry and Animal Behaviour, FAL, Germany.

Gupta, N., Pandey, A., Malik, G. and Gupta, S. 2009. Single nucleotide polymorphism (SNP) in growth hormone gene of Jakhrana, a prominent milk goat breed in India. Small Ruminant Research, 81, 3541.

Hailu, A. andGetu, A. 2015. Breed characterization tools and their applications. International Journal of Genetics, 5, 7-14.

Haley, C. S. andKnott, S. A. 1992. A simple regression method for mapping quantitative trait loci in line crosses using flanking markers. Heredity, 69, 315-324.

Haley, C. S., Knott, S. A. andElsen, J. 1994. Mapping quantitative trait loci in crosses between outbred lines using least squares. Genetics, 136, 1195-1207.

Hayes, B., Bowman, P., Chamberlain, A., Verbyla, K., andGoddard, M. 2009. Accuracy of genomic breeding values in multi-breed dairy cattle populations. Genetics Selection, Evolution, 41(1), 51.

Herraez D.L, Schafer H., Mosner J., Fries H.R.and Wink M. (2005). Comparison of microsatellite and single nucleotide polymorphism markers for the genetic analysis of a galloway cattle population. Z Naturforsch C 60, 637-643.

Higgs, R., Lynn, D. J., Gaines, S., Mcmahon, J., Tierney, J., James, T., Lloyd, A. T., Mulcahy, G. andO'farrelly, C. 2005. The synthetic form of a novel chicken $\beta$-defensin identified in silico is predominantly active against intestinal pathogens. Immunogenetics, 57, 90-98.

Hou, J., An, X., Song, Y., Wang, J., Ma, T., Han, P., Fang, F. and Cao, B. 2013. Combined effects of four snps within goat prlr gene on milk production traits. Gene, 529, 276-281. 
Hua, G., Chen, S., Yu, J., Cai, K., Wu, C., Li, Q., Zhang, C., Liang, A., Han, L. and Geng, L. 2009. Polymorphism of the growth hormone gene and its association with growth traits in Boer goat bucks. Meat Science, 81, 391-395.

Hull, K. and Harvey, S. 2002. GH as a cogonadotropin: the relevance of correlative changes in GH secretion and reproductive state. The Journal of Endocrinology, 172, 1-19.

Ikeobi, C., Woolliams, J., Morrice, D., Law, A., Windsor, D., Burt, D. and Hocking, P. 2002. Quantitative trait loci affecting fatness in the chicken. Animal Genetics, 33, 428-435.

Inoue, A., Takahashi, K. A., Arai, Y., Tonomura, H., Sakao, K., Saito, M., Fujioka, M., Fujiwara, H., Tabata, Y. and Kubo, T. 2006. The therapeutic effects of basic fibroblast growth factor contained in gelatin hydrogel microspheres on experimental osteoarthritis in the rabbit knee. Arthritis and Rheumatism: Official Journal of the American College of Rheumatology, 54, 264-270.

Jawasreh, K., Al-Rawashdeh, I., Al-Majali, A., Talafha, H., Eljarah, A. and Awawdeh, F. 2011. Genetic relatedness among Jordanian local Awassi lines Baladi, Sagri and Blackface and the black Najdi breed using RAPD analysis. Genomics Quant Genet, 2, 31-6.

Jawasreh, K., Amareen, A. A. and Aad, P. 2019. Effect and interaction of $\beta$-Lactoglobulin, Kappa Casein, and Prolactin genes on milk production and composition of Awassi sheep. Animals, 9,382 .

Jin, Q., Sun, J., Fang, X., Zhang, C., Yang, L., Chen, D., Shi, X., Du, Y., Lan, X. and Chen, H. 2011. Molecular characterization and polymorphisms of the caprine Somatostatin (SST) and SST Receptor 1 (SSTR1) genes that are linked with growth traits. Molecular Biology Reports, 38, 3129-3135.

Kalinowski, S. T., Taper, M. L. and Marshall, T. C. 2007. Revising how the computer program CERVUS accommodates genotyping error increases success in paternity assignment. Molecular Ecology, 16, 1099-1106.

Kaminski, S., Oleński, K., Brym, P., Malewski, T. and Sazanov, A. 2006. Single nucleotide polymorphism in the promoter region of the lactoferrin gene and its associations with milk performance traits in Polish Holstein-Friesian cows. RussianJournal of Genetics, 42, 924-927.

Kaupe, B., Brandt, H., Prinzenberg, E. and Erhardt, G. 2007. Joint analysis of the influence of CYP11B1 and DGAT1 genetic variation on milk production, somatic cell score, conformation, reproduction, and productive lifespan in German Holstein cattle. Journal of Animal Science, 85, 11-21.

Khatib, H., Leonard, S., Schutzkus, V., Luo, W. and Chang, Y. 2006. Association of the OLR1 gene with milk composition in Holstein dairy cattle. Journal of Dairy Science, 89, 1753-1760.

Khatib, H., Zaitoun, I., Chang, Y., Maltecca, C. and Boettcher, P. 2007. Evaluation of association between polymorphism within the thyroglobulin gene and milk production traits in dairy cattle. Journal of Animal Breeding and Genetics, 124, 26-28.

Lagziel, A., Lipkin, E. and Soller, M. 1996. Association between SSCP haplotypes at the bovine growth hormone gene and milk protein percentage. Genetics, 142, 945-951.

Lan, X., Pan, C., Chen, H., Lei, C., Hua, L., Yang, X., Qiu, G., Zhang, R. and Lun, Y. 2007. DdeI polymorphism in coding region of goat POU1F1 gene and its association with production traits. Asian-Australasian Journal of Animal Sciences, 20, 1342-1348.

Li, F., Chen, H., Lei, C., Ren, G., Wang, J., Li, Z. and Wang, J. 2010a. Novel SNPs of the bovine GAD1/gad67 gene and their association with growth traits in three native Chinese cattle breeds. Molecular Biology Reports, 37, 501-505.

Li, F., Chen, H., Lei, C., Ren, G., Wang, J., Li, Z. and Wang, J. 2010b. Novel SNPs of the bovine NUCB2 gene and their association with growth traits in three native Chinese cattle breeds. Molecular Biology Reports, 37, 541-546.

Li, J., Liang, A., Li, Z., Du, C., Hua, G., Salzano, A., Campanile, G., Gasparrini, B. and Yang, L. 2017. An association analysis between PRL genotype and milk production traits in Italian Mediterranean river buffalo. Journal of Dairy Research, 84, 430-433.

Liu, Y., Lan, X., Qu, Y., Li, Z., Chen, Z., Lei, C., Fang, X. and Chen, H. 2011. Effects of genetic variability of the dairy goat growth hormone releasing hormone receptor (GHRHR) gene on growth traits. Molecular Biology Reports, 38, 539-544.

Liu, Y., Zan, L., Xin, Y., Tian, W., Li, L. and Wang, H. 2013. ZBTB38 gene polymorphism associated with body measurement traits in native Chinese cattle breeds. Gene, 513, 272-277.

Lu, J., Hou, S., Huang, W., Yu, J. and Wang, W. 2011. Polymorphisms in the myostatin gene and their association with growth and carcass traits in duck. African Journal of Biotechnology, 10, 11309-11312.

Ma, G.W., Chu, Y.K., Zhang, W.J., Qin, F.Y., Xu, S.S., Yang, H., Rong, E.G., Du, Z.Q., Wang, S.Z. and Li, H. 2017. Polymorphisms of FST gene and their association with wool quality traits in Chinese Merino sheep. PloS One, 12, e0174868.

Ma, L., Qin, Q., Yang, Q., Zhang, M., Zhao, H., Pan, C., Lei, C., Chen, H. and Lan, X. 2017. Associations of six SNPs of POU1F1-PROP1PITX1-SIX3 pathway genes with growth traits in two Chinese indigenous goat breeds. Annals of Animal Science, 17, 399-411.

Macgillivary, J. 2009.Evaluation of Prka Genes as Candidates for Milk Production in Cattle. M.Sc. thesis, Dalhousie University, Canada.

Magotra, A., Gupta, I., Verma, A., Alex, R. and Ahmad, T. 2019. Candidate SNP of CACNA2D1 gene associated with clinical mastitis and 
production traits in Sahiwal (Bos taurus indicus) and Karan Fries (Bos taurus taurus $\times$ Bos taurus indicus). Animal Biotechnology, 30, 75-81.

Mahrous, K., Hassanane, M., Shafey, H., Mordy, M. A. and Rushdi, H. 2016. Association between single nucleotide polymorphism in ovine Calpain gene and growth performance in three Egyptian sheep breeds. Journal of Genetic Engineering and Biotechnology, 14, 233-240.

Manly, K. F., Cudmore Jr, R. H. andMeer, J. M. 2001. Map Manager QTX, cross-platform software for genetic mapping. Mammalian Genome, 12, 930-932.

Maudet, C., Luikart, G. andTaberlet, P. 2002. Genetic diversity and assignment tests among seven French cattle breeds based on microsatellite DNA analysis. Journal of Animal Science, 80, 942-950.

Mclean, K. and Schmutz, S. 2011. Melanocortin 4 receptor polymorphism is associated with carcass fat in beef cattle. Canadian Journal of Animal Science, 91, 75-79.

Mclean, K. L. and Schmutz, S. M. 2009. Associations of melanocortin 1 receptor genotype with growth and carcass traits in beef cattle. Canadian Journal of Animal Science, 89, 295300.

Medrano, J. F. and Cordova, E. A. 1990. Genotyping of bovine kappa-casein loci following DNA sequence amplification. Biotechnology, 8, 144146.

Migdal, L., Koziol, K., Palka, S., Migdal, W., Zabek, T., Otwinowska-Mindur, A., Migdal, A., Kmiecik, M., Maj, D. and Bieniek, J. 2018. Mutations in leptin (LEP) gene are associated with carcass and meat quality traits in crossbreed rabbits. Animal Biotechnology, 29, 153-159.

Misra, S., Sharma, A., Bhattacharya, T., Kumar, P. and Roy, S. S. 2008. Association of breed and polymorphism of as1-and as2-caseingenes with milk quality and daily milk and constituent yield traits of buffaloes (Bubalus bubalis). Buffalo Bull, 27, 294-301.

Morammazi, S. andHabibi, H. 2017. Sequence Variation in GAL1 and GAL2 genes in Khuzestan local chickens. European Online Journal of Natural and Social Sciences, 6, pp. 508-515.

Mu, F., Rong, E., Jing, Y., Yang, H., Ma, G., Yan, X., Wang, Z., Li, Y., Li, H. and Wang, N. 2017. Structural characterization and association of ovine Dickkopf-1 gene with wool production and quality traits in Chinese Merino.Genes, 8,400 .

Meuwissen, TH., Hayes, B. and Goddard, M. 2001. Prediction of total genetic value using genomewide dense marker maps. Genetics, 157, 18191829.

Nadeem, A. and Maryam, J. 2016. Genetic and genomic dissection of Prolactin revealed potential association with milk production traits in riverine buffalo. Tropical Animal Health and Production, 48, 1261-1268.

Nagy, E. D., Chu, Y., Guo, Y., Khanal, S., Tang, S., Li, Y., Dong, W. B., Timper, P., Taylor, C. and Ozias-Akins, P. 2010. Recombination is suppressed in an alien introgression in peanuthar boring Rma, a dominant root-knot nematode resistance gene. Molecular Breeding, 26, 357370 .

Narayanan, S. 1991. Applications of restriction fragment length polymorphism. Ann. Clin. Lab Sci., 21, 291-296.

Negahdary, M., Majdi, S. and Hajihosseinlo, A. 2014. Genetic effect of IGF1, PIT1 and Leptin genes on wool weights in Makooei sheep. Electron J Biol, 10, 46-51.

Nicolazzi, E. L., Picciolini, M., Strozzi, F., Schnabel, R. D., Lawley, C., Pirani, A., Brew, F. andStella, A. 2014. SNPchiMp: a database to disentangle the SNPchip jungle in bovine livestock. BMC Genomics, 15, 123-28.

Noshahr, F. A. and Rafat, A. 2014. Polymorphism of DGAT1 gene and its relationship with carcass weight and dressing percentage in Moghani sheep breed. IranJ Appl Anim Sci, 4, 331-334.

Otaviano, A. R., Tonhati, H., Sena, J. A. D. and Cerón Muñoz, M. F. 2005. Kappa-casein gene study with molecular markers in female buffaloes (Bubalus bubalis). Genetics and Molecular Biology, 28, 237-241.

Othman, O. E., Zayed, F. A., El Gawead, A. A. and El-Rahman, M. R. 2011. Genetic polymorphism of two genes associated with carcass trait in Egyptian buffaloes. Journal of Genetic Engineering and Biotechnology, 9, 15-20.

Othman, O. E., El-Fiky, S. A., Hassan, N. A., Mahfouz, E. R. and Balabel, E. A. 2013. Genetic polymorphism detection of two $\alpha$-Casein genes in three Egyptian sheep breeds. Journal of Genetic Engineering and Biotechnology, 11, 129-134.

Othman, O. E., Nowier, A. M., El-Kader, H., ElAziem, S. H. A. and Youssef, Y. 2015. Genetic characterization of fibroblast growth factor-5 gene in rabbits. Global Veterinaria, 14, 453-458.

Pagan, M. 2002.Evaluation of serum insulin-like growth factor binding proteins and the insulinlike growth factor binding protein-2 locus for potential associations with growth, carcass merit and meat quality in beef cattle, Ph.D thesis, Department of Animal Science, Michigan State University, USA.

Page, B., Casas, E., Heaton, M., Cullen, N., Hyndman, D., Morris, C., Crawford, A., Wheeler, T., Koohmaraie, M. and Keele, J. 2002. Evaluation of single-nucleotide polymorphisms in CAPN1 for association with meat tenderness in cattle. Journal of Animal Science, 80, 3077-3085.

Pariset, L., Cappuccio, I., Marsan, P. A., Dunner, S., Luikart, G., England, P., Obexer-Ruff, G., Peter, C., Marletta, D. andPilla, F. 2006. Assessment of population structure by single nucleotide 
polymorphisms (SNPs) in goat breeds. Journal of Chromatography B, 833, 117-120.

Pauciullo, A., Cosenza, G., Steri, R., Coletta, A., Jemma, L., Feligini, M., Di Berardino, D., Macciotta, N. P. and Ramunno, L. 2012a. An association analysis between OXT genotype and milk yield and flow in Italian Mediterranean river buffalo. Journal of Dairy Research, 79, 150-156.

Pauciullo, A., Cosenza, G., Steri, R., Coletta, A., La Battaglia, A., Di Berardino, D., Macciotta, N. P. and Ramunno, L. 2012b. A single nucleotide polymorphism in the promoter region of river buffalo stearoyl CoA desaturase gene (SCD) is associated with milk yield. Journal of Dairy Research, 79, 429-435.

Peakall, R. andSmouse, P. E. 2012. GenAlEx 6.5: Genetic analysis in Excel. Population genetic software for teaching and research an update. Bioinformatics, 28, 2537-2539.

Peiró, R., Merchan, M., Santacreu, M. A., Argente, M. J., García, M. L., Folch, J. M. and Blasco, A. 2008. Identification of single-nucleotide polymorphism in the progesterone receptor gene and its association with reproductive traits in rabbits. Genetics, 180, 1699-1705.

Peng, J., Zhang, G.-W., Zhang, W.-X., Liu, Y.-F., Yang, Y. and Lai, S.-J. 2013. Rapid genotyping of MSTN gene polymorphism using highresolution melting for association study in rabbits. Asian-Australasian Journal of Animal Sciences, 26, 30-35.

Piyasatian, N., Fernando, R. L., and Dekkers, J. C. M. 2007. Genomic selection for marker assisted improvement in line crosses. Theoretical and Applied Genetics, 115(5), 665-674.

Qasim, M., Ahmad, H., Ghafoor, S., Afridi, S., Muhammad, I. andImtiaz, A. 2011. Estimation of genetic diversity in sheep (Ovis aries) using randomly amplified polymorphic DNA. International Journal of Animal and Veterinary Advances, 3, 6-9.

Rasmussen, H. B. 2012. Restriction fragment length polymorphism analysis of PCR-amplified fragments (PCR-RFLP) and gel electrophoresisvaluable tool for genotyping and genetic fingerprinting. Gel electrophoresis-principles and basics. In Techopen.

Raymond, M. 1995. GENEPOP (version 1.2): Population genetics software for exact tests and ecumenicism. J. Hered., 86, 248-249.

Rolim, Filho, S., Ribeiro, H., De Camargo, G., Cardoso, D., Aspilcueta-Borquis, R., Tonhati, H., Nunes, K., Vale, W., Barbosa, E. and De Sousa, K. 2013. Identification of polymorphisms in the Osteopontin gene andtheir associations with certain semen production traits of water buffaloes in the B razilian Amazon. Reproduction in Domestic Animals, 48, 705-709.

Russo, V., Fontanesi, L., Scotti, E., Tazzoli, M., Dall'olio, S. and Davoli, R. 2007. Analysis of melanocortin 1 receptor (MC1R) gene polymorphisms in some cattle breeds: their usefulness and application for breed traceability and authentication of Parmigiano Reggiano cheese. Italian Journal of Animal Science, 6, 257272.

Russo, V., Fontanesi, L., Dolezal, M., Lipkin, E., Scotti, E., Zambonelli, P., Dall'olio, S., Bigi, D., Davoli, R. and Canavesi, F. 2012. A whole genome scan for QTL affecting milk protein percentage in Italian Holstein cattle, applying selective milk DNA pooling and multiple marker mapping in a daughter design. Animal Genetics, 43, 72-86.

Sahwan, F. M., El-Sheik, A. I., Sharaf, M. M. and ElNahas, A. F. 2014. Genetic polymorphism in growth hormone receptor gene $(G H R)$ and its relationship with growth trait in pure and hybrid rabbit breeds. Alexandria Journal for Veterinary Sciences, 43, 45-51.

Saleh, M. 2019. Using bioinformatics SNP to improve immune genetic response against some pathogens in poultry. M Sc. Thesis, In cooperation between Faculty of Agriculture at Moshtohor, Benha University and Tempus European Union program, Italy, 2019.

Schaeffer, L. 2006. Strategy for applying genome-wide selection in dairy cattle. Journal of Animal Breeding and Genetics, 123, 218-223.

Scotti, E., Fontanesi, L., Schiavini, F., La Mattina, V., Bagnato, A. and Russo, V. 2010. DGAT1 p. K232A polymorphism in dairy and dual purpose Italian cattle breeds. Italian Journal of Animal Science, 9, e16.

Seidel, G. 2009. Brief introduction to whole-genome selection in cattle using single nucleotide polymorphisms. Reproduction, Fertility and Development, 22, 138-144.

Sevane, N., Armstrong, E., Cortes, O., Wiener, P., Wong, R. P., Dunner, S. and Consortium, G. 2013. Association of bovine meat quality traits with genes included in the PPARG and PPARGC1A networks. Meat Science, 94, 328335.

Sharma, A., Dutt, G., Sivalingam, J., Singh, M., Pathodiya, O., Khadda, B. and Dixit, S. 2013. Novel SNPs in IGF1, GHR and IGFBP-3 genes reveal significant association with growth traits in Indian goat breeds. Small Ruminant Research, 115, 7-14.

Sharma, A., Lee, J. S., Dang, C. G., Sudrajad, P., Kim, H. C., Yeon, S. H., Kang, H. S. andLee, S.H. 2015. Stories and challenges of genome wide association studies in livestock- A review. Asian-Australasian Journal of Animal Sciences, 28, 1371-1379.

Solberg, T. R., Sonesson, A. K., andWoolliams, J. A. 2008.Genomic selection using different marker types and densities.Journal of Animal Science, 86(10), 2447-2454.

Sugiarto, H. andYu, P.-L. 2004. Avian antimicrobial peptides: the defense role of $\beta$-defensins. 
Biochemical and Biophysical Research Communications, 323, 721-727.

Sulayman, A., Tursun, M., Sulaiman, Y., Huang, X., Tian, K., Tian, Y., Xu, X., Fu, X., Mamat, A. and Tulafu, H. 2018. Association analysis of polymorphisms in six keratin genes with wool traits in sheep. Asian-Australasian Journal of Animal Sciences, 31, 775-783.

Szkiba, D., Kapun, M., Von Haeseler, A. andGallach, M. 2014. SNP2GO: functional analysis of genome-wide association studies. Genetics, 197, 285-289.

Talebi, R., Ahmadi, A., Afraz, F., Sarry, J., Woloszyn, F. and Fabre, S. 2018. Detection of single nucleotide polymorphisms at major prolificacy genes in the Mehraban sheep and association with litter size. Annals of Animal Science, 18, 685-698.

Tanpure, T., Dubey, P. K., Singh, K. P., Kathiravan, P., Mishra, B. P., Niranjan, S. K. and Kataria, R. S. 2012. PCR-SSCP analysis of leptin gene and its association with milk production traits in river buffalo (Bubalus bubalis). Tropical Animal Health and Production, 44, 1587-1592.

Tellam, R. L., Cockett, N. E., Vuocolo, T. and Bidwell, C. A. 2012. Genes contributing to genetic variation of muscling in sheep. Frontiers in Genetics, 3, 1-14.

Thue, T. and Buchanan, F. 2003. Linkage mapping of POMC to bovine chromosome 11. Animal Genetics, 34, 149-150.

Vanraden, P., Olson, K., Null, D. and Hutchison, J. 2011. Harmful recessive effects on fertility detected by absence of homozygous haplotypes. Journal of Dairy Science, 94, 6153-6161.

Wang, J., Li, G., Elzo, M. A., Yan, L., Chen, S., Jia, X. and Lai, S. 2015. A novel single nucleotide polymorphism of the POU1F1 gene associated with meat quality traits in rabbits. Annals of Animal Science, 15, 611-620.

Wang J, E. M., Linjun, Y., Chen, S., Jia, X., Zhang, M. and Lai, S. 2016. A single nucleotide polymorphism in CAST gene is associated with meat quality traits in rabbits. Animal Science Papers and Reports, 24, 269-278.

Wang, X., Maltecca, C., Tal-Stein, R., Lipkin, E. and Khatib, H. 2008. Association of bovine fibroblast growth factor 2 (FGF2) gene with milk fat and productive life: An example of the ability of the candidate pathway strategy to identify quantitative trait genes. Journal of Dairy Science, 91, 2475-2480.

White, S., Casas, E., Wheeler, T., Shackelford, S., Koohmaraie, M., Riley, D., Chase Jr, C., Johnson, D., Keele, J. and Smith, T. 2005. A new single nucleotide polymorphism in CAPN1 extends the current tenderness marker test to include cattle of Bos indicus, Bos taurus, and crossbred descent. Journal of Animal Science, 83, 2001-2008.

Williams, J. G., Kubelik, A. R., Livak, K. J., Rafalski, J. A. andTingey, S. V. 1990. DNA polymorphisms amplified by arbitrary primers are useful as genetic markers. Nucleic Acids Research, 18, 6531-6535.

Wojdak-Maksymiec, K., Kmiec, M. and Ziemak, J. 2006. Associations between bovine lactoferrin gene polymorphism and somatic cell count in milk. Veterinarni Medicina-PRAHA-, 51, 14-20.

Woollard, J., Schmitz, C., Freeman, A. and Tuggle, C. 1994. Rapid communication: HinfI polymorphism at the bovine Pit-1 locus. Journal of Animal Science, 72, 3267-3267.

Wu, Z., Chen, S., Jia, X. and Lai, S. 2015. Association of a synonymous mutation of the PGAM2 gene and growth traits in rabbits. Czech J. Anim. Sci, 60, 139-144.

Xu, Q., Tang, G., Zhang, Q., Huang, Y., Liu, Y., Quan, K., Zhu, K. and Zhang, C. 2011. The FABP4 gene polymorphism is associated with meat tenderness in three Chinese native sheep breeds. Czech Journal of Animal Science, 56, 1-6.

Yang, G. 2014.Characterisation of genes associated with sheep growth and carcass traits. $\mathrm{PhD}$ Thesis. Lincoln University, New Zealand.

Yang, M., Lv, J., Zhang, L., Li, M., Zhou, Y., Lan, X., Lei, C. and Chen, H. 2017. Association study and expression analysis of CYP4A11 gene copy number variation in Chinese cattle. Scientific Reports, 7,46599.

Yang, Z.J., Fu, L., Zhang, G.W., Yang, Y., Chen, S.Y., Wang, J. andLai, S.J. 2013. Identification and association of SNPs in TBC1D1 gene with growth traits in two rabbit breeds. AsianAustralasian Journal of Animal Sciences, 26, 1529-1535.

Zabeau, M. andVos, P. 1993. Selective restriction fragment amplification: A general method for DNA fingerprinting. European Patent Office, publication, 534-858 A1, bulletin 93/13.

Zaghloul, A.F.R. 2019. Crossbreeding effects on some semen and litter traits in rabbits. M Sc. Thesis. Faculty of Agriculture at Moshtohor, Benha University, Egypt.

Zetouni, L., De Camargo, G. M. F., Da Silva Fonseca, P. D., Gil, F. M. M., Lugo, N. A. H., Aspilcueta-Borquis, R. R., Cervini, M. and Tonhati, H. 2013. Effects of a single nucleotide polymorphism in the leptin gene on the productive traits of dairy buffaloes (Bubalus bubalis). Molecular Biology Reports, 40, 51595163.

Zetouni, L., De Camargo, G. M. F., Da Silva Fonseca, P. D., Cardoso, D. F., Gil, F. M. M., Hurtado-Lugo, N. A., Aspilcueta-Borquis, R. R., Cervini, M. and Tonhati, H. 2014. Polymorphisms in the MTRN1A gene and their effects on the productive and reproductive traits in buffaloes. Tropical Animal Health and Production, 46, 337-340.

Zhang, C., Zhang, W., Luo, H., Yue, W., Gao, M. and Jia, Z. 2008. A new single nucleotide polymorphism in the IGF-I gene and its 
association with growth traits in the Nanjiang Huang goat. Asian-Australasian Journal of Animal Sciences, 21, 1073-1079.

Zhang, C., Liu, Y., Huang, K., Zeng, W., Xu, D., Wen, Q. and Yang, L. 2011. The association of two single nucleotide polymorphisms (SNPs) in growth hormone $(\mathrm{GH})$ gene with litter size and superovulation response in goat-breeds. Genetics and Molecular Biology, 34, 49-55.

Zhang, C., Liu, Y., Xu, D., Wen, Q., Li, X., Zhang, W. and Yang, L. 2012. Polymorphisms of myostatin gene (MSTN) in four goat breeds and their effects on Boer goat growth performance. Molecular Biology Reports, 39, 3081-3087.

Zhang, J., Zan, L., Fang, P., Zhang, F., Shen, G. andTian, W. 2008. Genetic variation of PRLR gene and association with milk performance traits in dairy cattle. Canadian Journal of Animal Science, 88, 33-39

Zhang, L., Ma, X., Xuan, J., Wang, H., Yuan, Z., Wu, M., Liu, R., Zhu, C., Wei, C. and Zhao, F. 2016. Identification of MEF2B and TRHDE gene polymorphisms related to growth traits in a new Ujumqin sheep population. PloS One, 11, $\mathrm{e} 0159504$.

Zhang, X., Wu, X., Jia, W., Pan, C., Li, X., Lei, C., Chen, H. and Lan, X. 2015. Novel nucleotide variations, haplotypes structure and associations with growth related traits of goat at motif-binding factor (ATBF1) gene. Asian-Australasian Journal of Animal Sciences, 28, 1394-1406.

Zhang, Y., Cui, W., Yang, H., Wang, M., Yan, H., Zhu, H., Liu, J., Qu, L., Lan, X. and Pan, C. 2019. A novel missense mutation (L280V) within POU1F1 gene strongly affects litter size and growth traits in goat. Theriogenology.135:198203.

Zhang, Z., Ling, Y., Wang, L., Hang, Y., Guo, X., Zhang, Y., Ding, J. and Zhang, X. 2013. Polymorphisms of the myostatin gene (MSTN) and its relationship with growth traits in goat breeds. Genetics and Molecular Research, 12, 965-971.

Zhao, H., Wu, X., Cai, H., Pan, C., Lei, C., Chen, H. and Lan, X. 2013. Genetic variants and effects on milk traits of the caprine paired-like homeodomain transcription factor 2 (PITX2) gene in dairy goats. Gene, 532, 203-210.

Zidi, A., Fernández-Cabanás, V., Urrutia, B., Carrizosa, J., Polvillo, O., González-Redondo, P., Jordana, J., Gallardo, D., Amills, M. and Serradilla, J. 2010. Association between the polymorphism of the goat stearoyl-CoA desaturase 1 (SCD1) gene and milk fatty acid composition in Murciano-Granadina goats. Journal of Dairy Science, 93, 4332-4339. 